\title{
Departures of 1996 Temperatures and Salinities in the Middle Atlantic Bight and Gulf of Maine from Historical Means
}

\author{
Robert L. Benway and Jack W. Jossi \\ Ecosystems Monitoring and Remote Sensing Branch, Northeast Fisheries Science Center \\ NOAA/NMFS, 28 Tarzwell Drive, Narragansett, RI 02882, USA
}

\begin{abstract}
Monthly monitoring of surface and water column temperature, and surface salinity across the Middle Atlantic Bight and Gulf of Maine has been conducted since 1976 and 1978, respectively. Presented are the temporal and spatial patterns of these features in 1996 and their comparisons to mean patterns for the base period, 1978-92. Middle Atlantic Bight surface and bottom temperatures and surface salinities during 1996 were the lowest since the beginning of the base period. Annual, 1996, averaged surface temperature over the entire transect was $1.9^{\circ} \mathrm{C}$ lower than the base period mean; similarly averaged bottom temperature was $-0.8^{\circ} \mathrm{C}$ cooler; and like averaged surface salinities was 1.17 PSU below that of the base period. In the more detailed time-space sense, Middle Atlantic Bight temperatures were significantly lower than average 1) over the mid- to outer shelf from February through April, 2) over the shelf and slope during July and August, 3) over the mid-shelf in October, and 4) well offshore in November. Negative departures of surface salinity occurred over the shelf throughout 1996 and after July over the entire transect reaching the Gulf Stream. Bottom temperatures were significantly below average on the mid-shelf during January, expanding inshore by April. Negative departures occurred over the outer shelf area during the early summer, and continued through most of the remainder of 1996. In the Gulf of Maine, annual, 1996 averaged surface temperature along the entire transect was $1.1^{\circ} \mathrm{C}$ below the baseline, and similarly averaged bottom temperature was $0.2^{\circ} \mathrm{C}$ above the mean. In the time-space sense, Gulf of Maine surface temperatures were significantly below the baseline from January through March in Massachusetts Bay, extending eastward to Crowell Basin in March. At this same time surface temperatures were as much as $4^{\circ} \mathrm{C}$ above average on the Scotian Shelf. From early July through September colder than average temperatures existed across the entire transect. Bottom temperatures were cooler than normal during January in Massachusetts Bay and in June through December on the Scotian Shelf. Starting in January over the central Gulf ledges warmer than average bottom temperatures were observed. Significant positive anomalies reached the Scotian Shelf in February, Massachusetts Bay by March and continued in the mid-Gulf until July.
\end{abstract}

Key words: bottom temperature, climatology, Gulf of Maine, Middle Atlantic Bight, surface salinity, surface temperature

\section{Introduction}

Scientific concern has been growing over the influence of climatic change on marine ecosystems. Oceanic factors, such as water temperature and salinity, have been shown to be of prime importance to resident and transient biota, because of direct and indirect environmental influences upon physiological processes such as metabolic rates and reproductive cycles (Colton and Stoddard, 1973). Furthermore, it has been suggested that a doubling of atmospheric carbon dioxide will occur sometime in the next century (Bolin et al., 1986), possibly resulting in an equilibrium global surface air temperature rise of $3^{\circ} \mathrm{C}$. Such a rise is expected to be nonuniform, with the greatest effects in higher latitudes, and with considerable regional differences. Such change will have important effects on the marine biota at scales ranging from individual organisms to whole ecosystems (Frank et al., 1988).

The Northwest Atlantic has been suggested as an area where the effects of major climatological change may become significant due to its proxim- 
ity to the boundary of the sub-polar and subtropical gyres, the fluctuations in major ocean currents, and high fish productivity (Meise-Munns et al., 1990). The need for time-series of fishery-relevant environmental data is critical to the retrospective analyses that are being applied to these problems (GLOBEC, 1989, 1991, 1991). The hydrographic properties of the Middle Atlantic Bight and Gulf of Maine are a complex array of important transient phenomena (Bowman and Wunderlich, 1977; Ingham, 1982; Mountain and Manning, 1994). Seasonal cycles of water temperature and salinity in these two geographic regions are strongly affected by patterns of insolation, river discharge, evaporation, winds and currents. Seasonal cycles of temperature and salinity are modified further by intrusions of slope water and Gulf Stream rings. Because of seasonal and interannual environmental variability, it is clear that long-term, systematic measurements of oceanographic conditions are essential to the detection and prediction of climatic changes and their influence on the living marine resources.

The British, since 1961, had been conducting monthly monitoring of $10 \mathrm{~m}$ depth plankton by using 1) merchant ships along the Scotian Shelf and across the Gulf of Maine, and 2) using US Coast Guard cutters going to and from the North Atlantic Ocean Stations Bravo and Delta (Glover, 1967). Beginning in the late-1960s the National Marine Fisheries Service (NMFS) established several interagency and international agreements that either started such monitoring, or supported the continuation of already existing ocean monitoring programs. Fostered by the global expedition of the United States Coastal and Geodetic Survey ship Oceanographer in 1967, a meeting was held in Plymouth, England, that led to a NMFS/United Kingdom cooperative agreement for the extension of the Continuous Plankton Recorder (CPR) survey into additional areas of the western North Atlantic. In the mid-1970 another cooperative agreement was developed between the NMFS and the US Maritime Administration to collect surface water samples and deploy expendable bathythermographs (XBTs) from merchant ships operating along the East and Gulf coasts of the United States. In 1972 a NMFS/US Coast Guard agreement was established to add neuston sampling and new CPR routes to their operations on standard Coast Guard cruises, and to bring all the ships of opportunity activities under the direction of the NMFS Marine Resources Monitoring, Assessment, and Prediction (MARMAP) Program (Sherman, 1980). As the program developed, routes were chosen across areas of interest to fisheries research, where regular water column and plankton sampling could be expected. The goal was to obtain no less than one transect per month of each route. The program has been known by several names over the years, but now is called the MARMAP Ships of Opportunity Program (SOOP). A summary of the products from this survey can be found in Benway et al. (1993). This report presents surface temperature and salinity, and bottom temperature conditions along the Middle Atlantic Bight transect and surface and bottom temperature conditions along the Gulf of Maine transect (Fig. 1a and $1 b$ ) during 1996, and describes their departures from average conditions for the fifteen-year period, 1978 through 1992.

\section{Methods}

The track lines of the ships of opportunity varied on different monthly occupations of a route. For consistency between sampling efforts, route polygons were developed for analysis and portrayal of the data collected. These polygons (Fig. 1a and 1b) were established based on composites of all sampling locations, such that oceanographic features were assumed to vary along the polygons' long axes, but to vary insignificantly normal to the long axes. Only data collected within the polygons were included in analyses. Standard reference positions were chosen for each route from which the radial distance to each sample location was calculated. These positions were located at such distances beyond the narrow ends of the polygons that arcs passing through the sample location had little curvature. The calculation also produced a reference distance, which was positive from North America seaward.

The Middle Atlantic Bight sampling (Fig. 1A) originated at Ambrose Tower $\left(40^{\circ} 27.5^{\prime} \mathrm{N}\right.$, $73^{\circ} 49.6^{\prime} \mathrm{W}$ ) and extended offshore approximately $500 \mathrm{~km}$ towards Bermuda. This was termed MARMAP Route MB, and the corners of this polygon were defined by the following geographic positions: $40^{\circ} 34^{\prime} \mathrm{N}, 74^{\circ} 00^{\prime} \mathrm{W} ; 40^{\circ} 20^{\prime} \mathrm{N}, 74^{\circ} 00^{\prime} \mathrm{W}$; $38^{\circ} 30^{\prime} \mathrm{N}, 69^{\circ} 00^{\prime} \mathrm{W}$; and $36^{\circ} 44^{\prime} \mathrm{N}, 70^{\circ} 30^{\prime} \mathrm{W}$. Sampling generally concluded within the Gulf Stream. Because of the Gulf Stream's varying position, not all sampling transects traversed the entire polygon length. A transect along this route typically passed through shelf, slope, and Gulf Stream water masses, and often crossed a portion of Deep Water Dumpsite 106. 


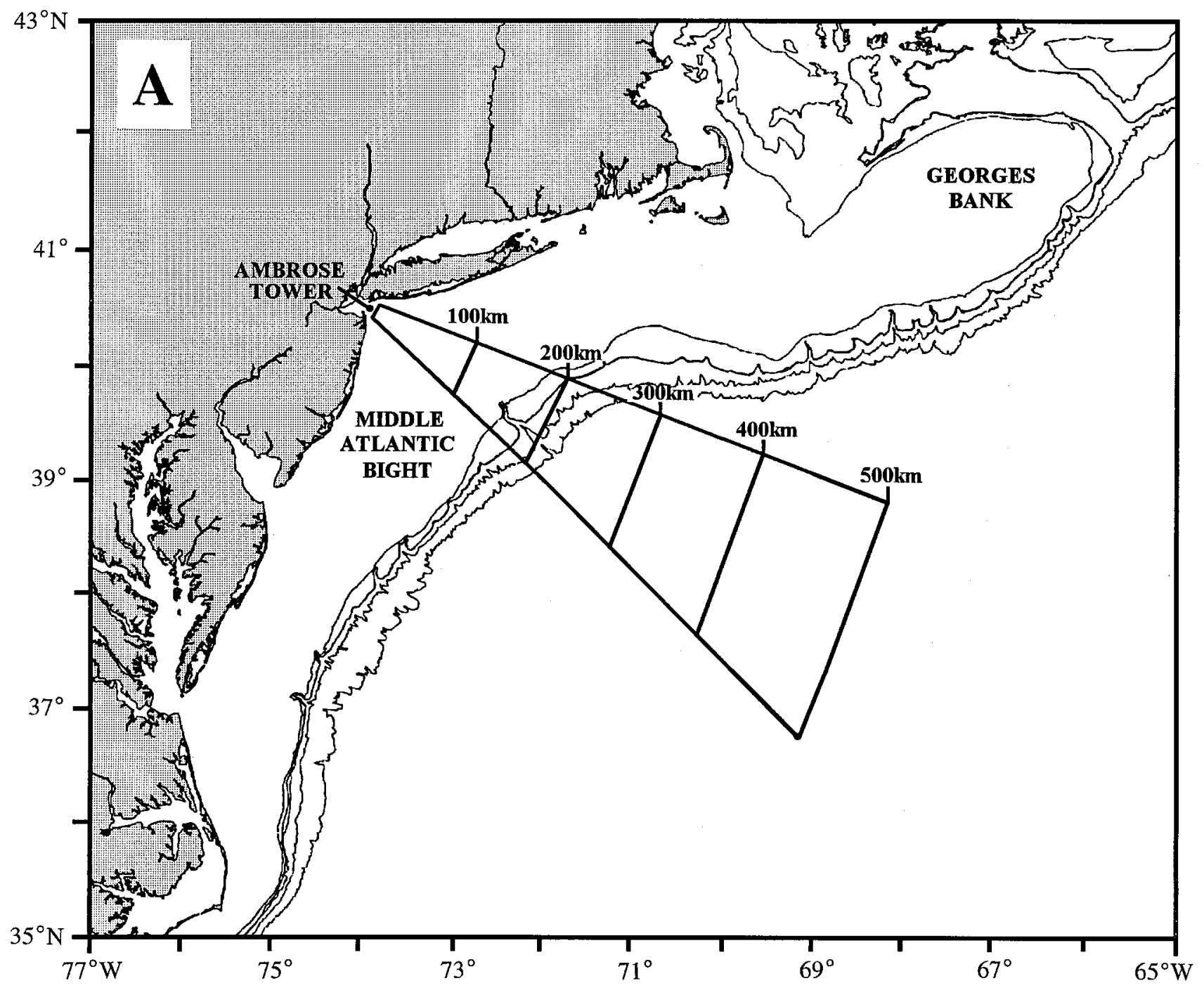

Fig. 1a. The Middle Atlantic Bight - Route MB polygon within which monitoring transects occurred, showing reference distances, location of Ambrose Tower, and major geographical features.

The Gulf of Maine sampling extended from the Massachusetts coast, to Cape Sable, Nova Scotia (Fig. 1B), for a distance of approximately $452 \mathrm{~km}$. This was termed MARMAP Route MC, and the corners of this polygon were defined by these geographic positions: $43^{\circ} 30^{\prime} \mathrm{N}, 71^{\circ} 00^{\prime} \mathrm{W} ; 43^{\circ} 30^{\prime} \mathrm{N}$, $65^{\circ} 37^{\prime} \mathrm{W} ; 43^{\circ} 00^{\prime} \mathrm{N}, 65^{\circ} 37^{\prime} \mathrm{W} ; 42^{\circ} 00^{\prime} \mathrm{N}, 71^{\circ} 00^{\prime} \mathrm{W}$. This polygon included the following geographic regions of the Gulf of Maine: Massachusetts Bay, Wilkinson Basin, the Central Gulf Ledges, southern Jordan Basin, Crowell Basin, and the Western Scotian Shelf.

\section{Data collection}

The regimen at every station included the following: deployment of an XBT probe, and concur- rent collection of a bucket sample for sea surface temperature calibration and salinity determination. In both polygons, XBTs were used to measure water column temperatures down to a maximum depth of $500 \mathrm{~m}$. Stations were positioned on the basis of time intervals rather than actual geographical locations. Sampling, on average, was hourly in the Middle Atlantic Bight and every two hours in the Gulf of Maine. Prior to 1981, all data were collected utilizing Sippican analog recorders, and traces were digitized. Thereafter, data were recorded digitally on magnetic tape or disk.

Ship position, time of XBT deployment, and water column depth (taken from a depth chart or fathometer) were logged and/or recorded in the 




Fig. 1b. The Gulf of Maine - route MC polygon, within which monitoring transects occurred, showing reference distances of the following: 1 = Massachusetts Bay, $2=$ Wilikinson Basin, $3=$ central Gulf ledges, 4 = Crowell Basin, 5 = Scotian Shelf, and major geographical features.

computer. (Note: full details on the MARMAP Ships of Opportunity Program (SOOP) operational procedures and theory are in preparation, and are available from the authors.)

\section{Temporal scales of the survey}

Monitoring of water temperature and salinity in the Middle Atlantic Bight and Gulf of Maine began in mid-year 1970. However, data collected before 1978 were too incomplete for inclusion in the development of the base period means. In the Middle Atlantic Bight one or two sampling cruises were conducted per month, generally during the first or second week of each month. Beginning in April 1990, approximately four sampling cruises were performed per month, generally one cruise per week. By comparison, there was one sampling cruise per month carried out across the Gulf of Maine, typically during the first week of each month. During 1986, no XBTs were deployed in the Gulf of Maine, so no bottom temperature data were collected. However, surface temperatue and salinity were measured in 1986.

\section{Spatial scales of the survey}

In Middle Atlantic Bight, a typical transect began with the first station at Ambrose Tower (reference distance $=17 \mathrm{~km})($ Fig. $1 \mathrm{~A})$. Generally, subsequent stations occurred about every hour (every 25-35 km depending on vessel speed), until the North Wall of the Gulf Stream was reached with the exception of those stations that were spaced at fifteen minute intervals $(7 \mathrm{~km})$ near the continental shelf break. The first station when traveling from Bermuda to New Jersey was at the Gulf Stream North Wall, with sampling at the same time intervals until reaching Ambrose Tower. Surface water samples and water column temperature profiles were collected at each station. 
In the Gulf of Maine, sampling was initiated from either end of the Route MC polygon (Fig. 1B). Surface water samples were collected every hour (every 20-30 km depending on vessel speed), and water column temperature profiles were obtained no less than every other hour.

\section{Data processing}

The depth of each XBT data value was derived as a function of time alone, using XBT descent equations from Sippican Corporation (1970). Although more recent equations exist, those cited are considered to be sufficiently accurate for this survey, and continue to be used for consistency. XBT voltages were converted to temperature according to Steinhart and Hart (1968) and Georgi et al. (1980).

Quality control software was designed specifically for the digital data format established in 1981 . For each sampling station of a given cruise, plots of temperature versus depth were produced, and all depth-temperature pairs were listed. The plots were then used to determine water column depth, surface temperature, and bottom temperature, as well as to delete inaccurate data. Surface bucket temperatures were used to calibrate surface probe values. Bottom depth was determined by comparing the log sheet depth with bottom impact marks on the plot, and bottom temperatures were chosen from corresponding values at that depth.

Conductivity measurements of sea surface samples were generated by use of a Guildline Model 8400 Autosal. Conductivities were converted to salinity values using the UNESCO standard equations of state (UNESCO, 1981).

Time-distance checks were performed on all recorded time and position data to eliminate erroneous $\log$ entries of the ship's position and/or logged time.

\section{Gridding}

Analyses of the data revealed considerable temporal and spatial variability for surface temperature, surface salinity and bottom temperature along most of the routes. As a result, a time-space gridding technique was developed to portray the data in a form that retained most of the original detail, to show long-term means and variances, and to determine departures in individual years from these means. Further, the technique permitted the extrac- tion of spatially coherent time series and analysis of relationships among measured values.

The design of the gridding method was developed in part with other research at the NOAA Narragansett Laboratory (Thomas, MS 1992; Benway et al., 1993). From each irregularly spaced raw data set, the gridding technique interpolated data values at regular, spatial-temporal grid points. Those gridded data values were contoured, producing three-dimensional representations of space by time by scalar. Furthermore, gridding was used to calculate mean values and standard deviations over the fifteen year base period (1978-92), individualyear differences from the base period mean values (algebraic anomalies), and standardized anomalies (algebraic anomalies/standard deviations).

Each grid was defined by route polygon reference distance (range: 0 to $452 \mathrm{~km}$ ) (Fig. $1 \mathrm{a}$ and $1 \mathrm{~b}$ ) along the $\mathrm{x}$-axis, time (range: 0 to 365.25 days) along the $y$-axis, and sample scalar values along the $\mathrm{z}$-axis. All grids were dimensioned such that grid points occurred at intervals of $17.38 \mathrm{~km}$ and 15.22 days, i.e. there were 27 grid columns (26 Divisions in $\mathrm{x}$ ) along each polygon, and 25 grid rows (24 Divisions in y) for every year or base period. At every grid point, a $Z$ value was calculated by performing an elliptical search in time and space, weighting all observed values within the ellipse, and calculating a weighted mean (Table 1). In the event of fewer than four observations within the search ellipse at a given grid point a missing value was assigned and any subsequent derived grids retained this blank value.

These methods and techniques were chosen by considering: 1) the average data coverage in time and space; 2) the closeness of fit between the actual data values and the interpolated grid values; 3) the grid size; 4) the spatial and temporal rates of change of the scalar values; and 5) the desire to ease interpretation and presentation of the final products. Statistics relating to this method are reported in Table 2 and Fig. 2 and 3.

An inherent bias in this gridding technique is the de-emphasis of extreme amplitudes in the raw data values. However, the tails of the residual distributions (Fig. 2) do not show that this is a severe problem. The standard deviations of the base period residuals are 2 to 3 times the corresponding standard deviations of the single year residuals. The small size of these latter residuals $\left(0.29-0.79^{\circ} \mathrm{C}\right.$, 
TABLE 1. Gridding methods and dimensions used for temperature and salinity data from the Middle Atlantic Bight and Gulf of Maine.

\begin{tabular}{|c|c|c|c|c|}
\hline Grid Type & $\begin{array}{l}\text { Minimum } \\
\text { Gridding Method }\end{array}$ & Search Radius & Data Points & Grid Limits \\
\hline Single Year & Kriging & $50 \mathrm{~km} \times 35$ days & 4 & $\begin{array}{c}0-452 \mathrm{~km} \\
0-365.25 \text { days }\end{array}$ \\
\hline $\begin{array}{l}\text { Base Period } \\
(1978-92)\end{array}$ & $\begin{array}{l}\text { Inverse Distance } \\
\text { Squared Weighting }\end{array}$ & $50 \mathrm{~km} \times 35$ days & 4 & $\begin{array}{c}0-452 \mathrm{~km} \\
0-365.25 \text { days }\end{array}$ \\
\hline
\end{tabular}

TABLE 2. Selected statistics from the gridding technique used on temperature and salinity data in the Middle Atlantic Bight and Gulf of Maine.

\begin{tabular}{clcc}
\hline \hline Time Span/Route & \multicolumn{1}{c}{ Data Type } & Mean of Residuals & $\begin{array}{c}\text { Standard Deviation } \\
\text { of Residuals }\end{array}$ \\
\hline $\begin{array}{l}\text { Single Year } \\
\text { MB }\end{array}$ & Surface temperature & -0.00017 & 0.751 \\
& Bottom temperature & 0.025 & 0.785 \\
& Surface salinity & 0.0079 & 0.377 \\
Base Period & & & \\
MB & Surface temperature & -0.023 & 1.865 \\
& Bottom temperature & -0.035 & 1.624 \\
& Surface salinity & 0.027 & 0.902 \\
Single Year & & & 0.424 \\
MC & Surface temperature & -0.0057 & 0.290 \\
& Bottom temperature & -0.0027 & 0.165 \\
& Surface salinity & -0.00041 & \\
Base Period & Surface temperature & -0.0031 & 1.129 \\
MC & Bottom temperature & -0.0387 & 0.8032 \\
& Surface salinity & -0.0209 & 0.4663 \\
\hline
\end{tabular}

0.17-0.38 PSU) indicate that, taken together, the base period grids and single year grids are a valid portrayal of the data. The remainder of this section will detail the gridding methodology applied to all data types.

The first step was to generate a mean grid from all data collected during the 1978-92 base period (Fig. 4-9, panel A). The mean grid for each base period was then used to generate a corresponding grid of standard deviations. To do so the base period mean grid surface was subtracted from observed values to produce a data set of residuals (Fig. 2 ), thereby removing the two-dimensional annual signal. A weighted variance was found by squaring all residual values, and then gridding these squared residuals. Finally, the standard deviation grid (Fig. 4-9, panel B) was created by taking the square root of the variance grid (the calculation did not include the number of observations, which exceeded 70 at all grid points).

Single year grids of observed, anomaly, and standardized anomaly values were generated for each route and data type. See Table 1 for single year grid methodology. Observed grids were created by gridding all observed data from that year (Fig. 1014, panel A). Anomaly grids were generated by first subtracting the base period mean value from each observed raw data value to obtain a data set of re- 


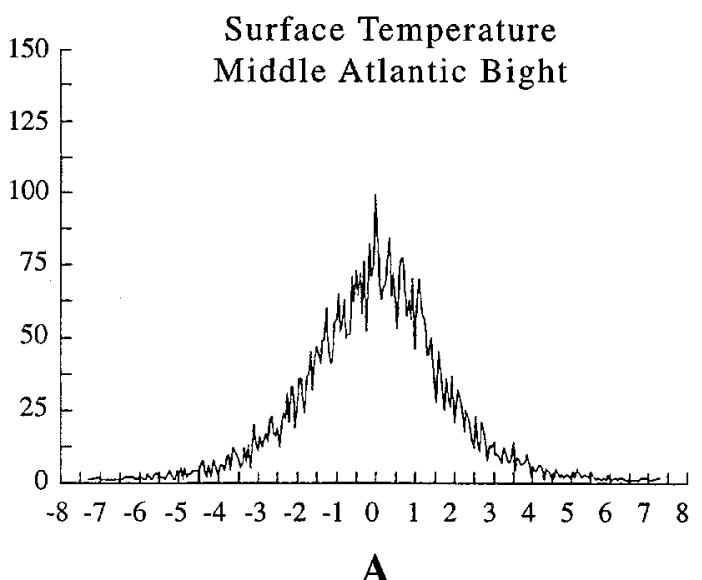

A

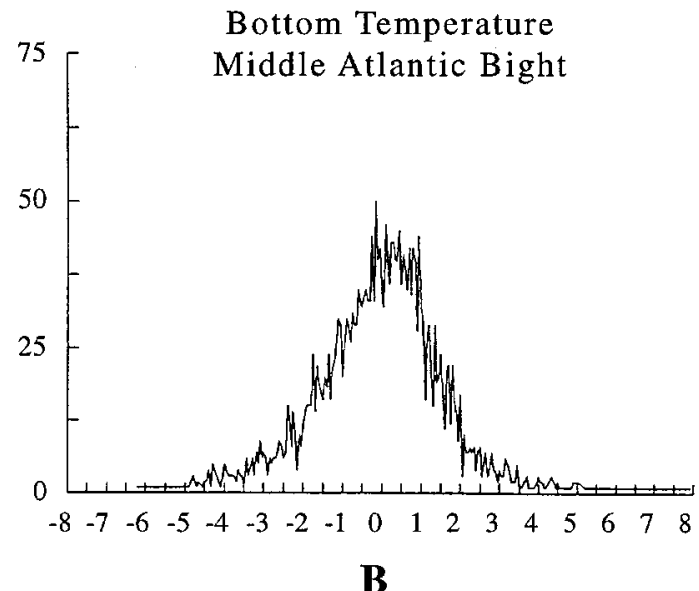

B

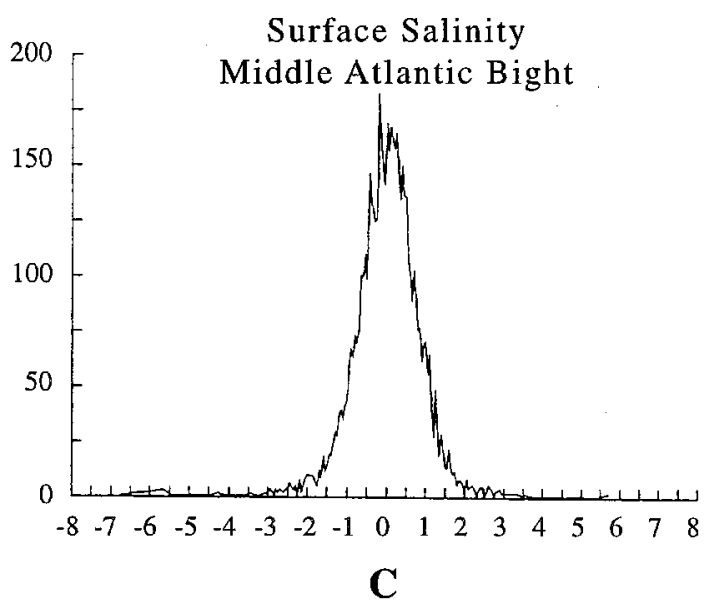

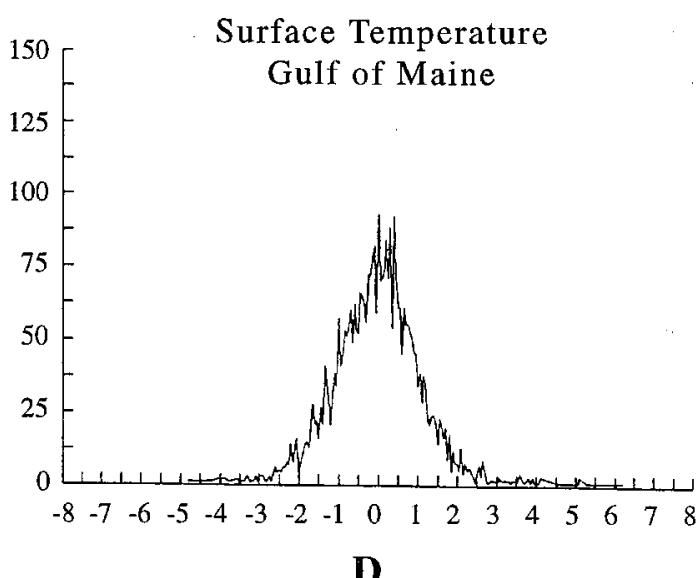
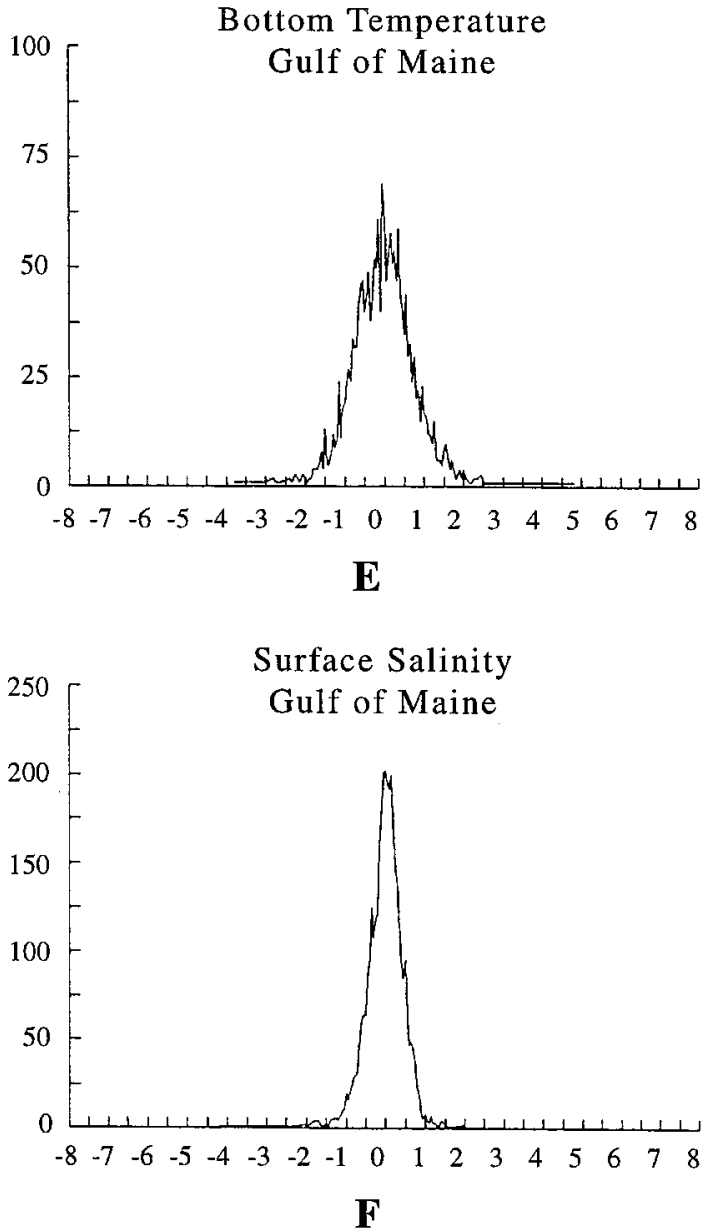

Fig. 2. Distribution of residuals from the base period grids. Panels A, B and C refer to surface temperature, bottom temperature, and surface salinity within the Middle Atlantic Bight sampling polygon respectively. Panels D, E, and F refer to the surface temperature, bottom temperature and surface salinity within the Gulf of Maine sampling polygon respectively. 


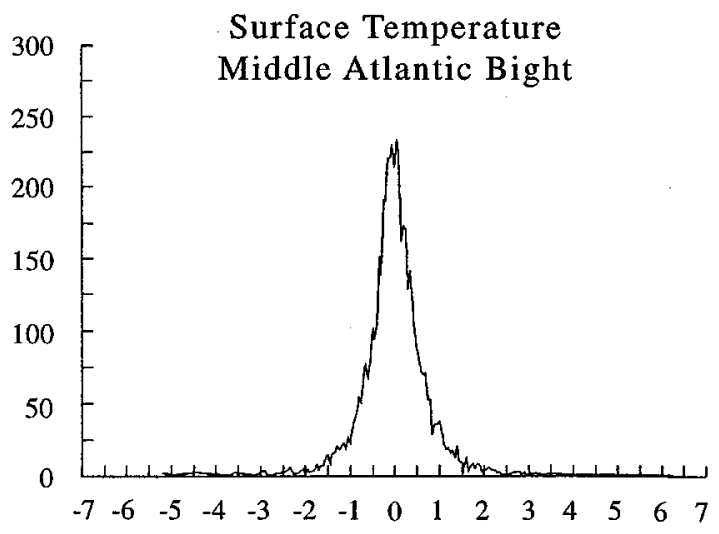

A
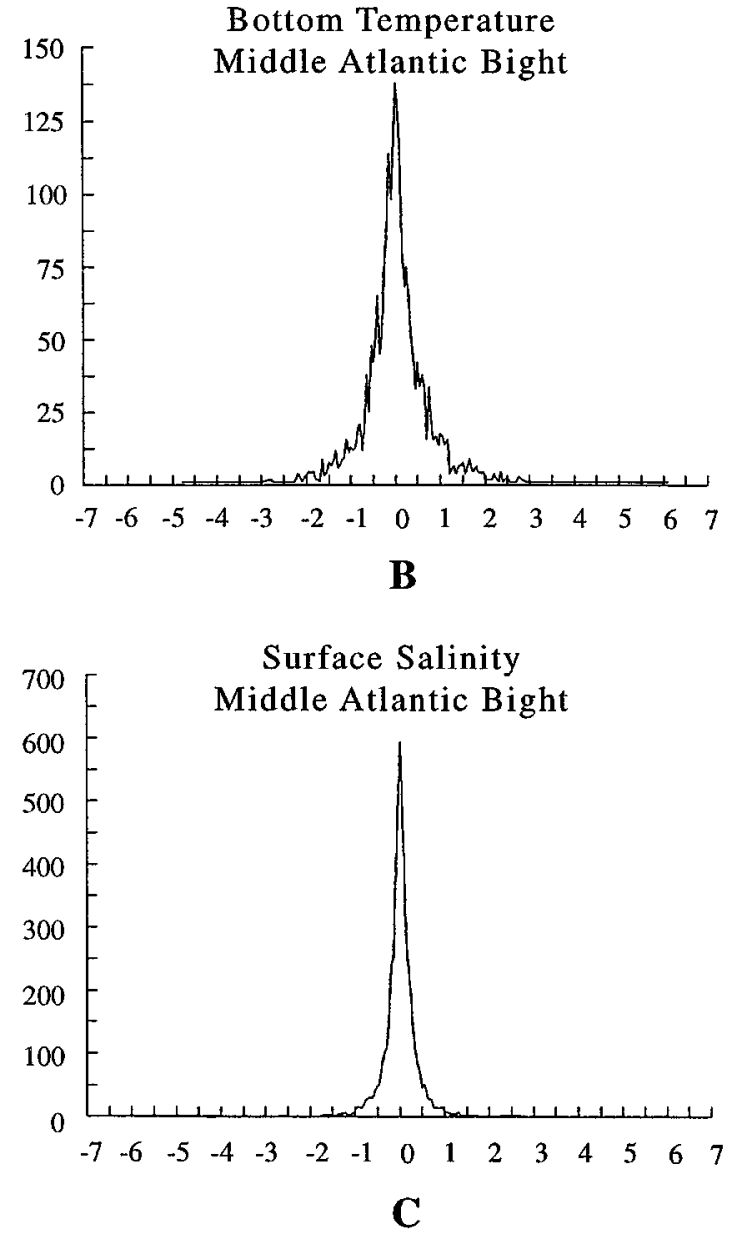
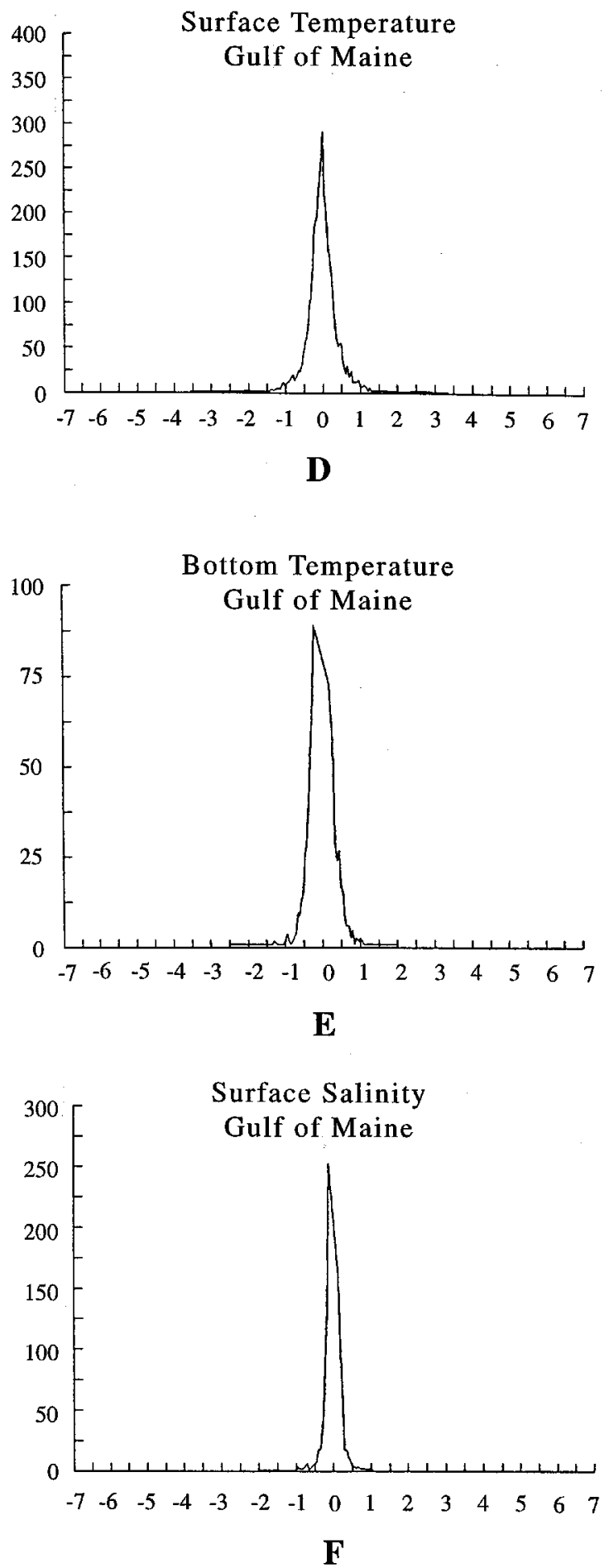

Fig. 3. Distribution of residuals from single year grids composited over all years, 1978 through 1992. Panels A, B and C refer to surface temperature, bottom temperature, and surface salinity within the Middle Atlantic Bight sampling polygon respectively. Panels D, E, and F refer to the surface temperature, bottom temperature and surface salinity within the Gulf of Maine sampling polygon, respectively. 


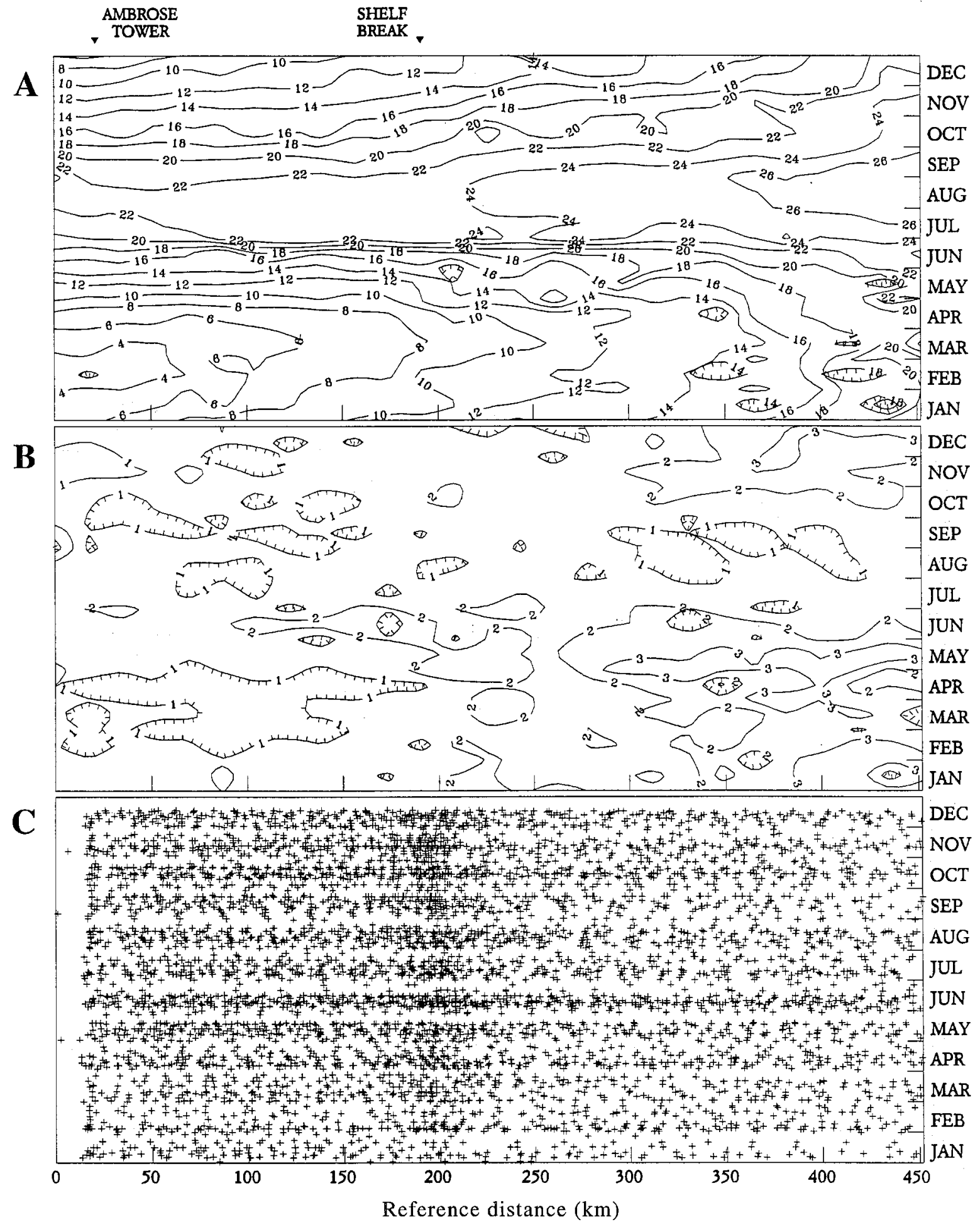

Fig. 4. Mean surface temperature conditions along the Middle Atlantic Bight route during 1978 through 1992. (A) means of measured values (degrees Celsius), (B) standard deviations of measured values (degrees Celsius) and (C) station locations in time and space. In panels A and B, values decline on those sides of contour lines with hatchers. 


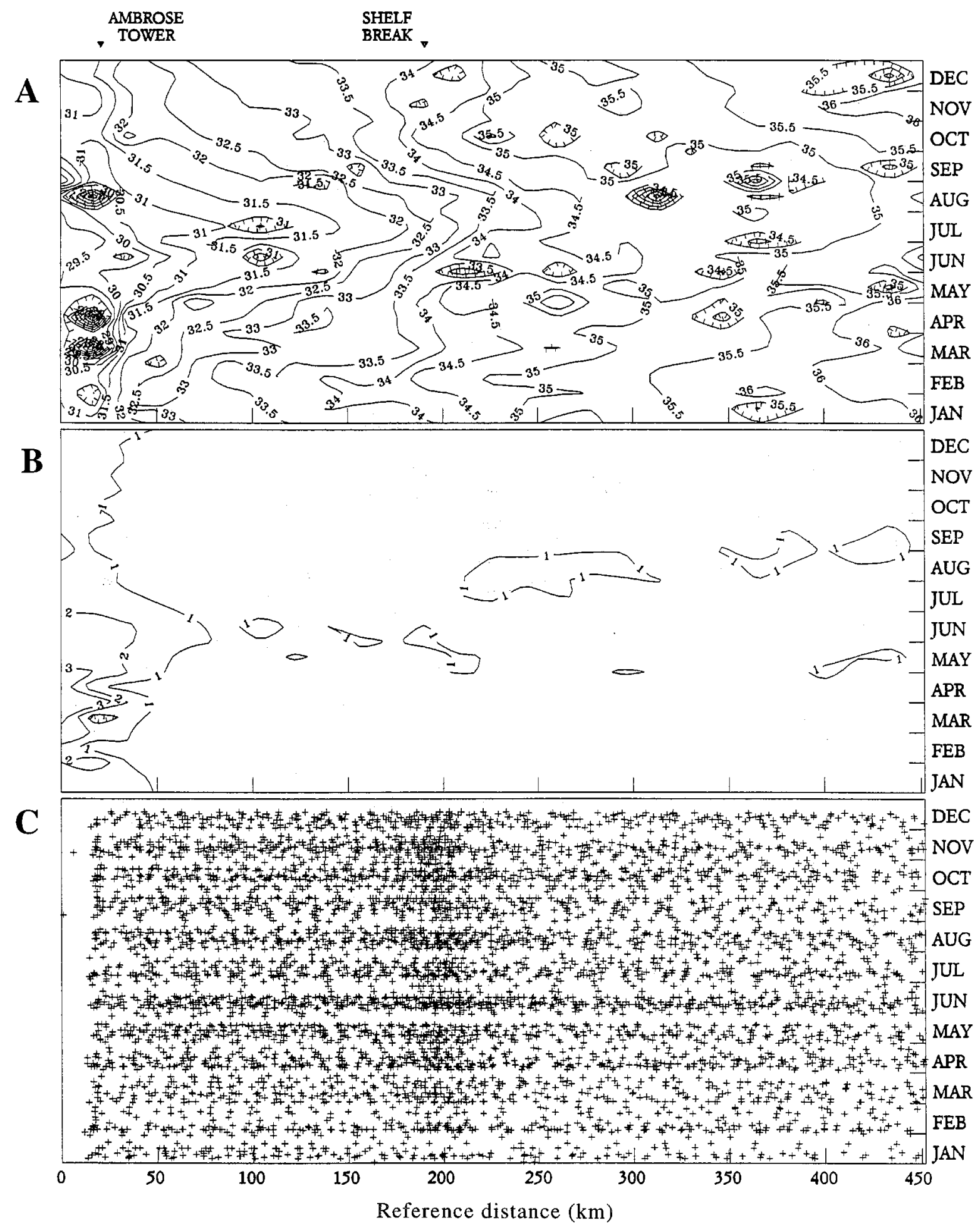

Fig. 5. Mean surface salinity conditions along the Middle Atlantic Bight route during 1978 through 1992. (A) means of measured values (practical salinity units), (B) standard deviations of measured values (practical salinity units) and (C) station locations in time and space. In panels A and B, values decline on those sides of contour lines with hatchers. 


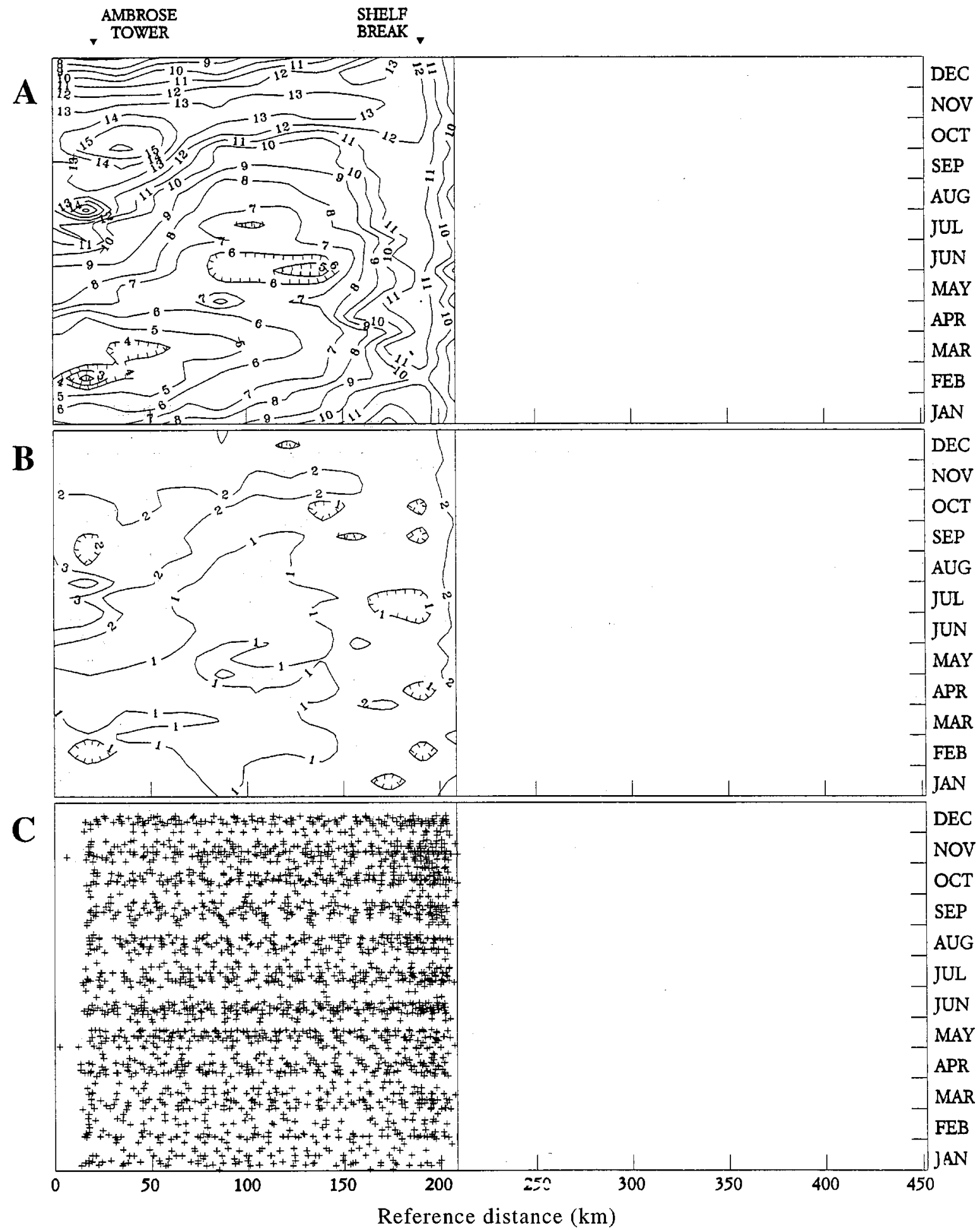

Fig. 6. Mean bottom temperature conditions along the Middle Atlantic Bight route during 1978 through 1992. (A) means of measured values (degrees Celsius), (B) standard deviations of measured values (degrees Celsius) and (C) station locations in time and space. In panels A and B, values decline on those sides of contour lines with hatchers. 


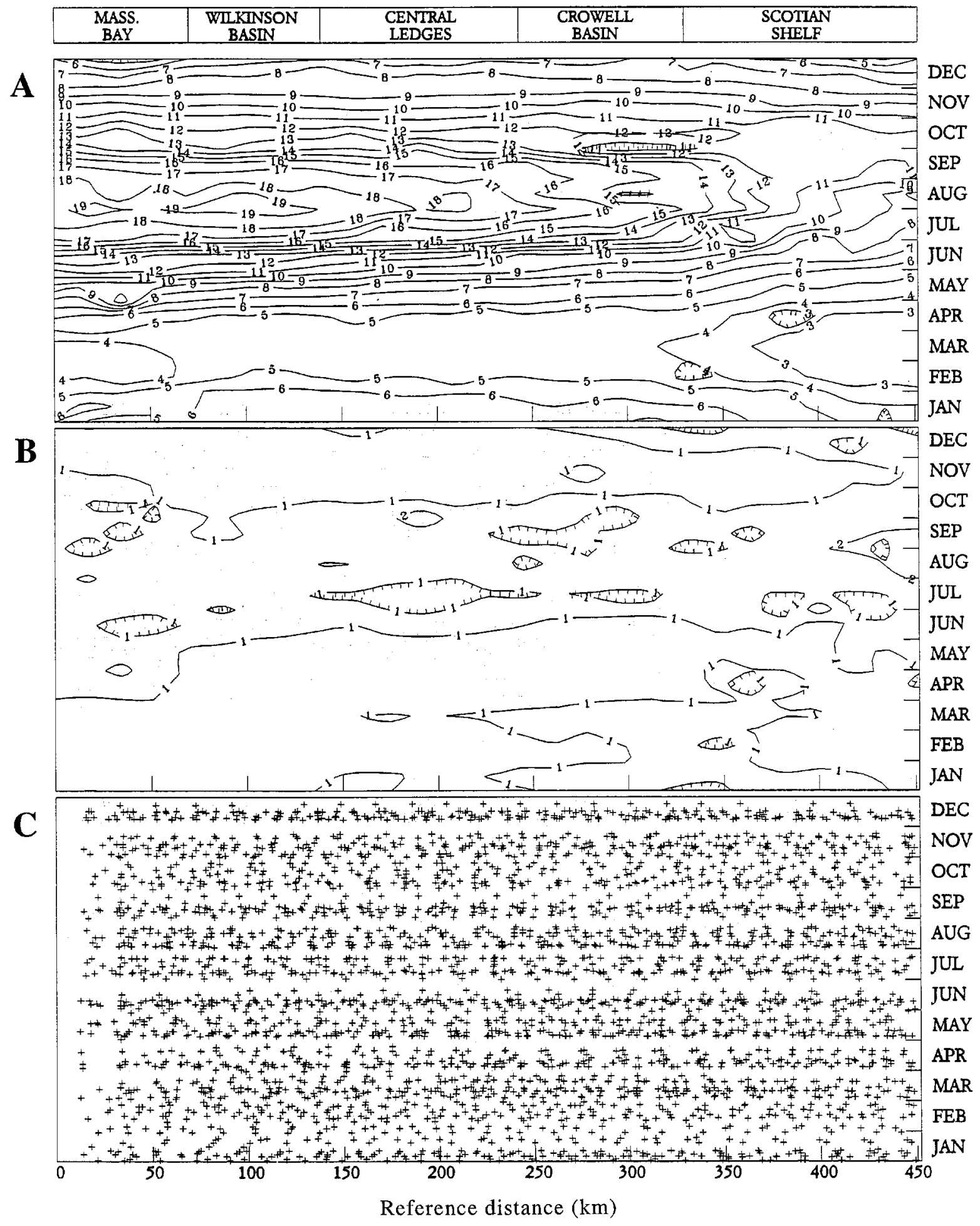

Fig. 7. Mean surface temperature conditions along the Gulf of Maine route during 1978 through 1992. (A) means of measured values (degrees Celsius). (B) standard deviations of measured values (degrees Celsius) and (C) station locations in time and space. In panels A and B, values decline on those sides of contour lines with hatchers. 


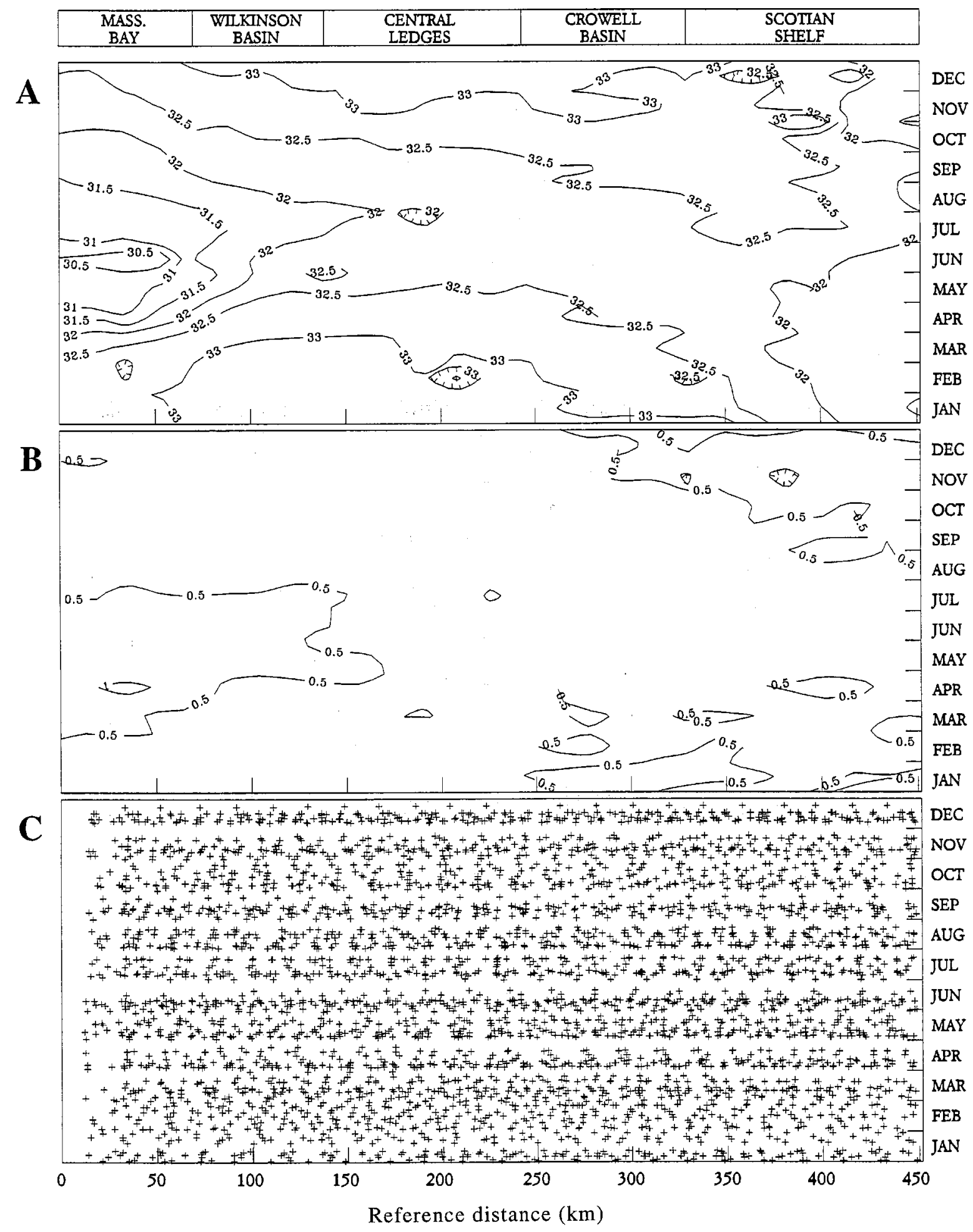

Fig. 8. Mean surface salinity conditions along the Gulf of Maine route during 1978 through 1992. (A) means of measured values (practical salinity units), (B) standard deviations of measured values (practical salinity units) and (C) station locations in time and space. In panels A and B, values decline on those sides of contour lines with hatchers. 


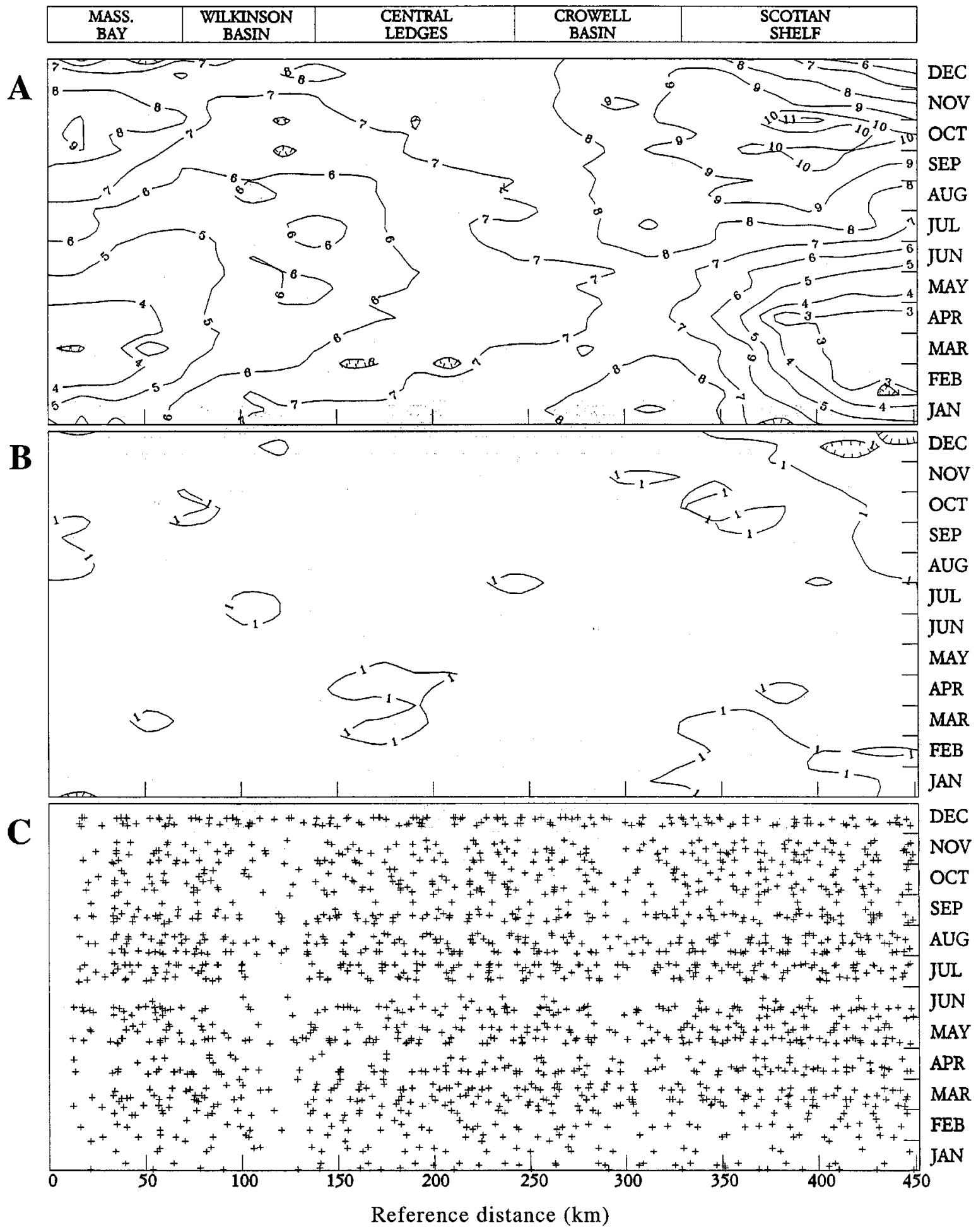

Fig. 9. Mean bottom temperature conditions along the Gulf of Maine route during 1978 through 1992. (A) means of measured values (degrees Celsius). (B) standard deviations of measured values (degrees Celsius) and (C) station locations in time and space. In panels A and B, values decline on those sides of contour lines with hatchers. 

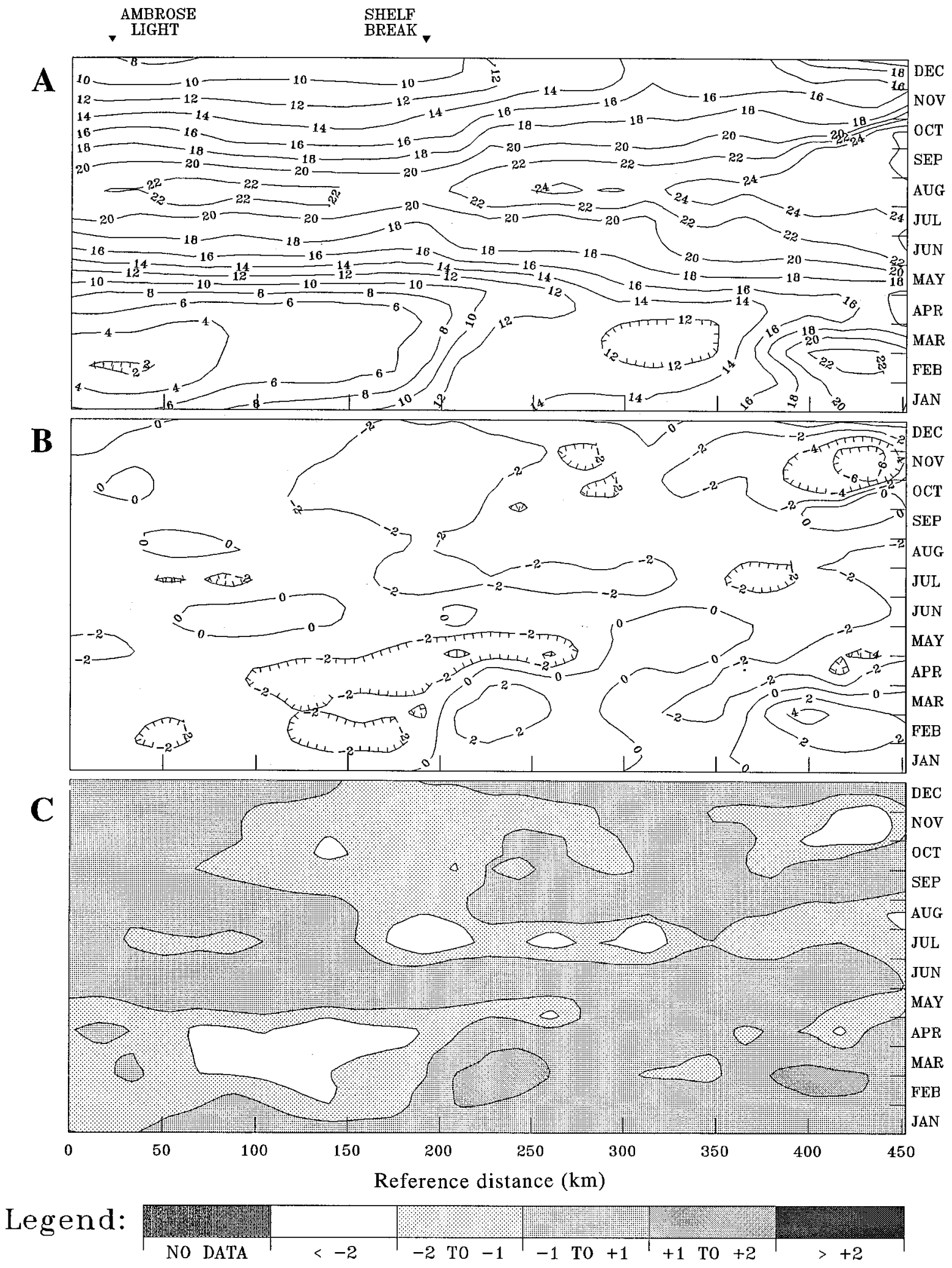

Fig. 10. Surface temperature conditions along the Middle Atlantic Bight transect during 1996. (A) measured values (degrees centigrade) in time and space. (B) Anomalies in time and space based on 1978 through 1992 means. (C) Standardized anomalies (standard deviations) in time and space based on 1978 through 1992 means and variances; scale given in legend. In panels A and B values decline on those sides of contour lines with hachures. 


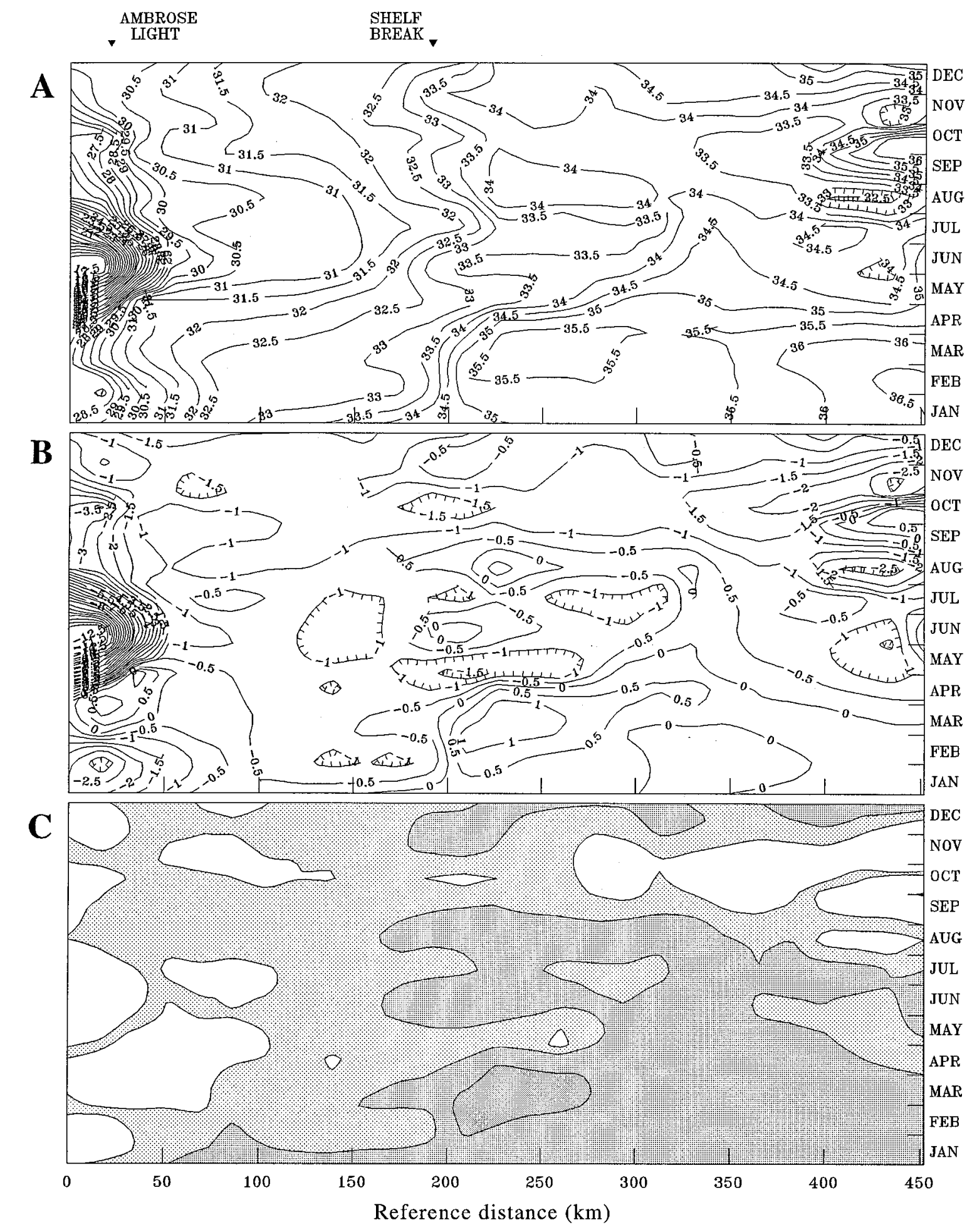

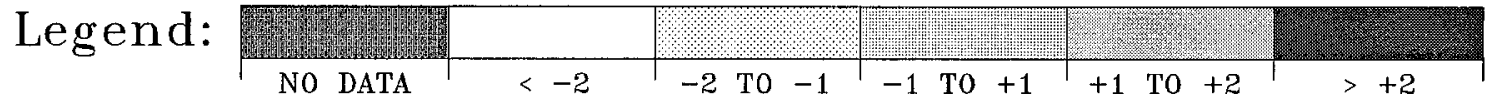

Fig. 11. Surface salinity conditions along the Middle Atlantic Bight transect during 1996. (A) measured values (practical salinity units) in time and space, (B) anomalies in time and space based on 1978 through 1992 means and (C) standardized anomalies (standard deviations) in time and space based on 1978 through 1992 means and variances; scale given in legend. In panels A and B values decline on those sides of contour lines with hachures. 

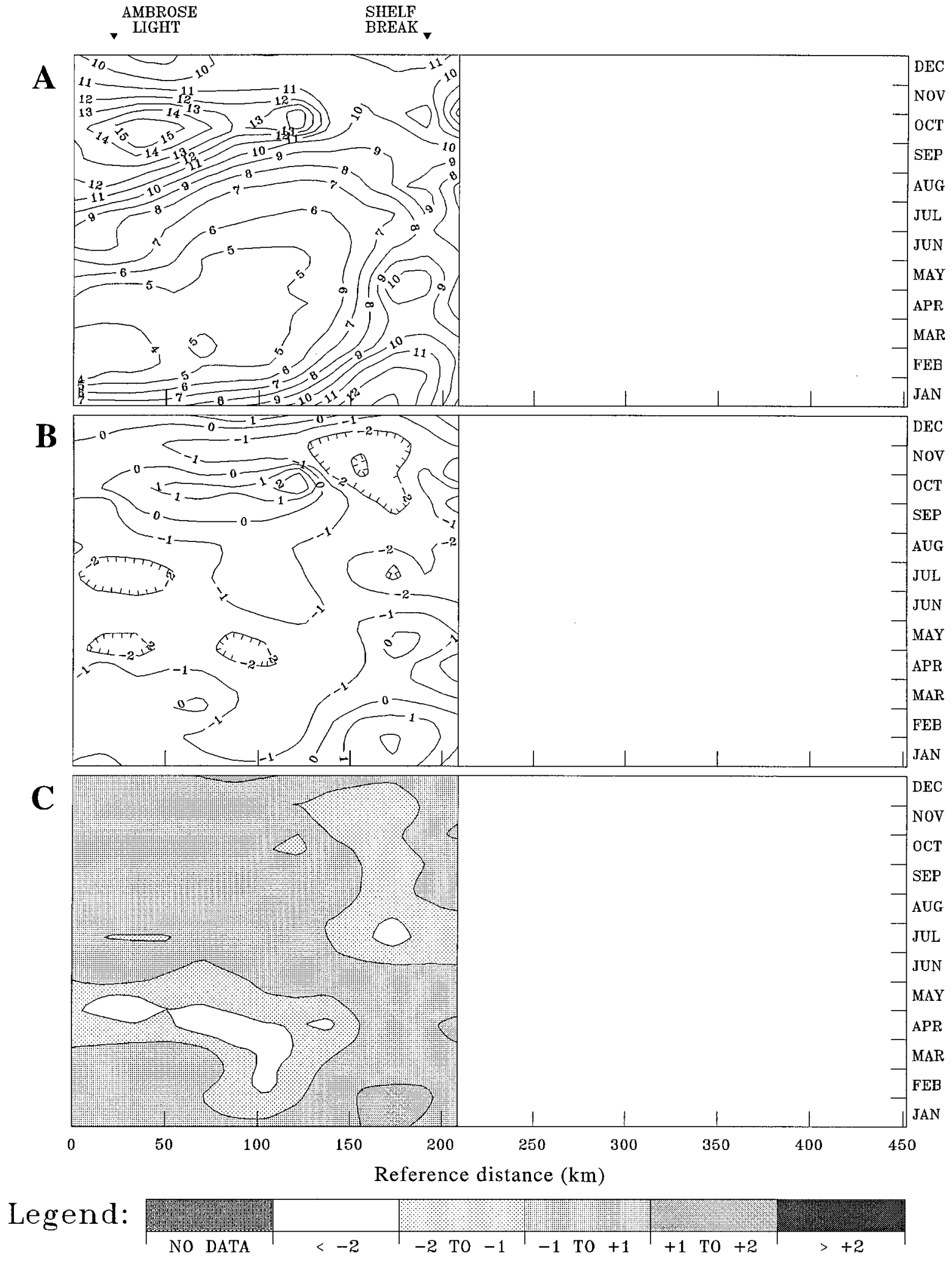

Fig. 12. Bottom temperature conditions along the Middle Atlantic Bight transect during 1996. (A) measured values (degrees centigrade) in time and space, (B) anomalies in time and space based on 1978 through 1992 means and (C) standardized anomalies (standard deviations) in time and space based on 1978 through 1992 means and variances; scale given in legend. In panels A and B values decline on those sides of contour lines with hachures. 


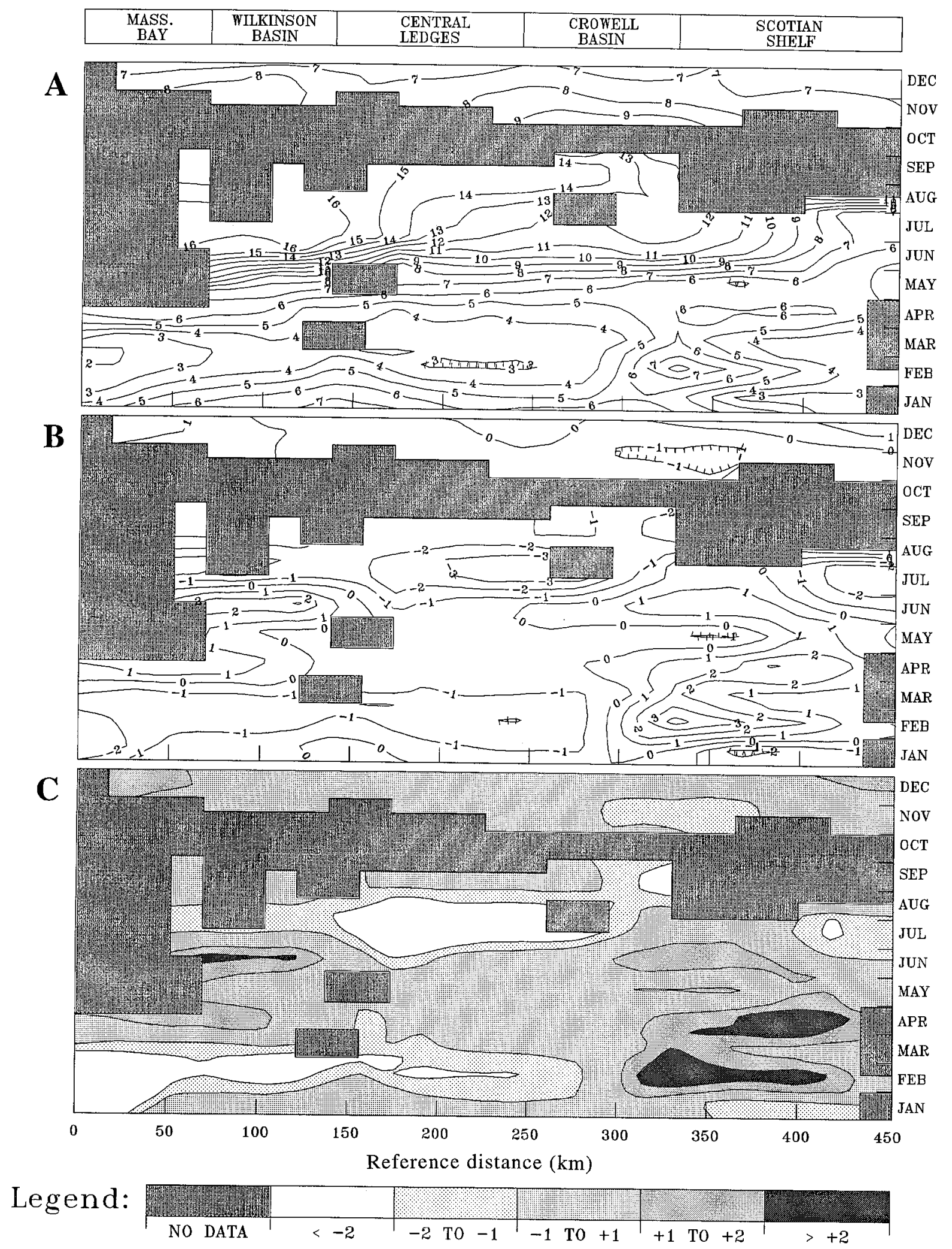

Fig. 13. Surface temperature conditions along the Gulf of Maine transect during 1996. (A) measured values (degrees centigrade) in time and space, (B) anomalies in time and space based on 1978 through 1992 means and (C) standardized anomalies (standard deviations) in time and space based on 1978 through 1992 means and variances; scale given in legend. In panels A and B values decline on those sides of contour lines with hachures. 


\begin{tabular}{|c|c|c|c|c|}
\hline $\begin{array}{c}\text { MASS. } \\
\text { BAY }\end{array}$ & $\begin{array}{c}\text { WILKINSON } \\
\text { BASIN }\end{array}$ & $\begin{array}{c}\text { CENTRAL } \\
\text { LEDGES }\end{array}$ & $\begin{array}{c}\text { CROWELL } \\
\text { BASIN }\end{array}$ & $\begin{array}{c}\text { SCOTIAN } \\
\text { SHELF }\end{array}$ \\
\hline
\end{tabular}

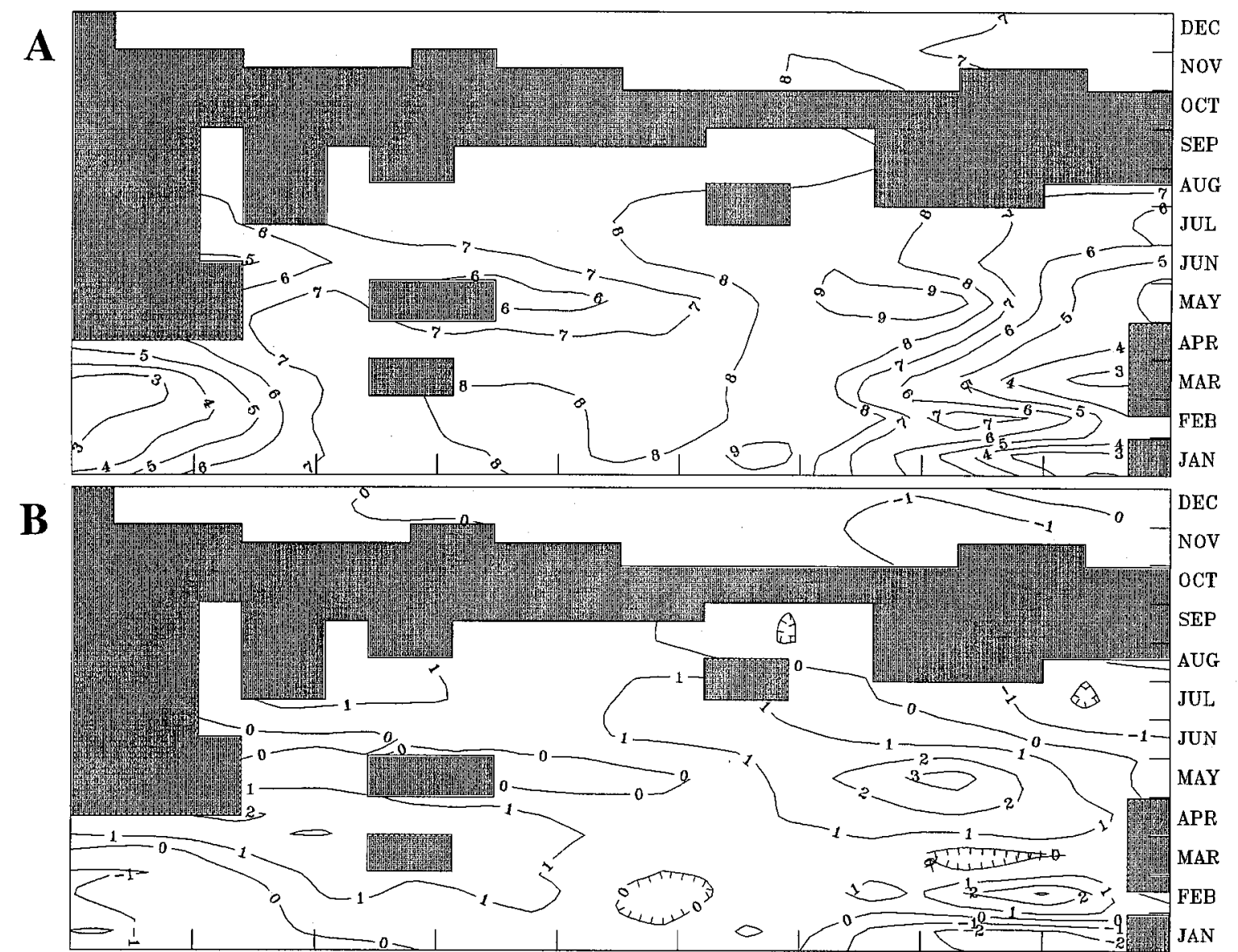

C
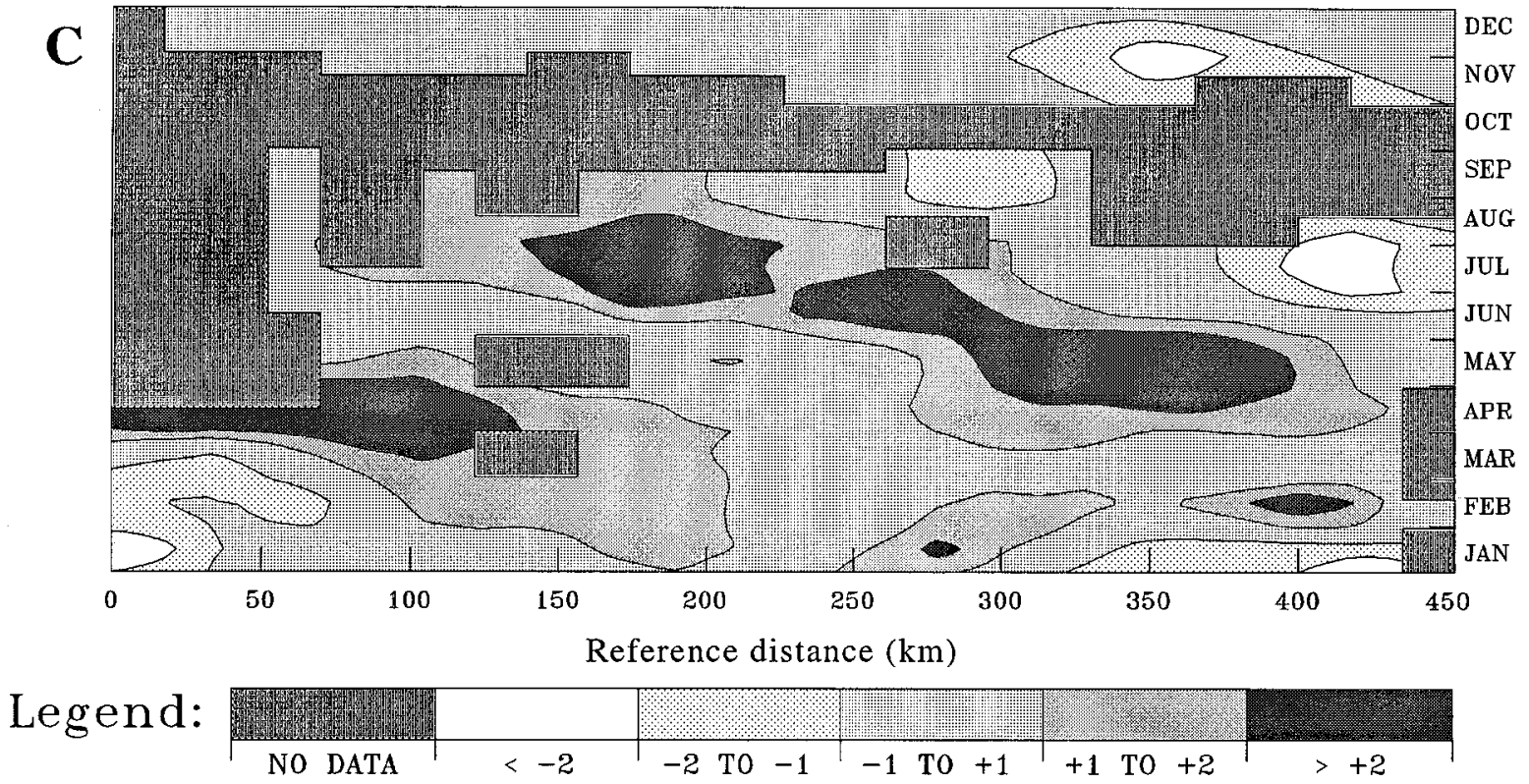

Fig. 14. Bottom Temperature conditions along the Gulf of Maine transect during 1996. (A) measured values (degrees centigrade) in time and space, (B) anomalies in time and space based on 1978 through 1992 means and (C) standardized anomalies (standard deviations) in time and space based on 1978 through 1992 means and variances; scale given in legend. In panels A and B values decline on those sides of contour lines with hachures. 

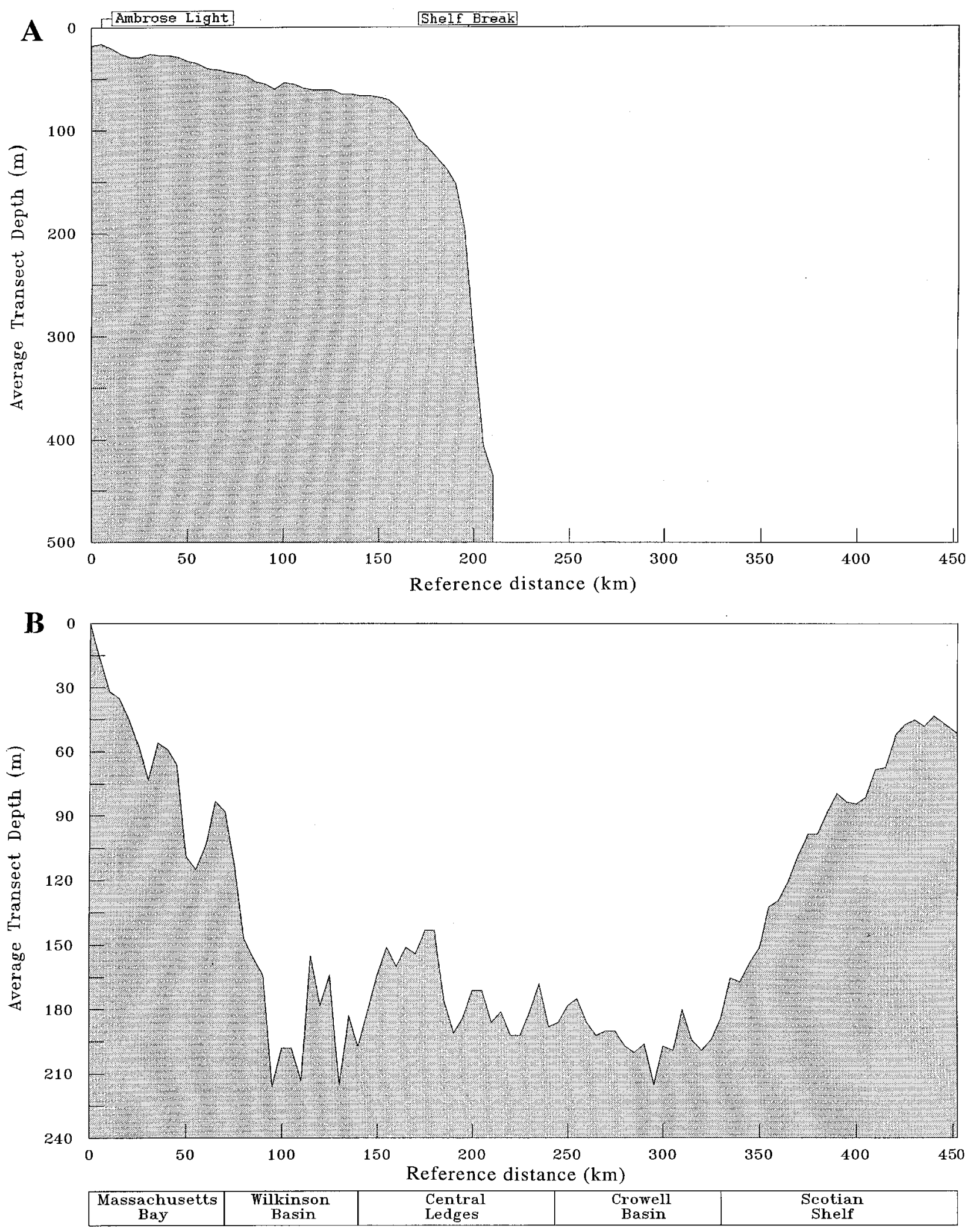

Fig. 15. Mean bottom depth along the transects based on monitoring survey data, 1978 through 1992. (A) Middle Atlantic Bight and (B) Gulf of Maine. 
siduals, and then gridding these residuals (Fig. 1014, panel B). By dividing the anomaly at each observation point by the corresponding interpolated standard deviation (taken from the base period standard deviation grid surface), standardized anomalies were calculated for every observation in a given year. Each annual standardized anomaly map was generated by gridding these standardized anomaly values (Fig. 10-14, panel C). For portrayal of statistically significant events, standardized anomaly map contour intervals were chosen by picking the $15.2 \%$ and $84.8 \%$ percentile levels, as an approximation of one standard deviation, and the $2.3 \%$ and 97.7\% percentile levels, as an approximation of two standard deviations, from the fifteen-year data set of standardized anomalies.

\section{Results}

The initial fifteen years of data collection (1978-92) were chosen to serve as a base period for computing long-term mean conditions, and for determining departures from mean conditions. Over the fifteen years, a total of 428 cruises were conducted in the Middle Atlantic Bight, and 313 cruises in the Gulf of Maine. Contoured, fifteen-year mean portrayals of surface temperature, bottom temperature, and surface salinity values are shown for the Middle Atlantic Bight (Fig. 4-6) and the Gulf of Maine (Fig. 7-9).

Each figure of fifteen-year mean conditions contains three panels: (A) contoured, gridded means of the observations for the base period; (B) estimated standard deviations of the gridded mean values; and (C) observed data locations during the base period.

Each single year contains three panels: (A) gridded, observed conditions with sampling locations; (B) departures of the observed conditions from the mean values expressed as algebraic anomalies; and (C) departures of the observed conditions from the mean values expressed as standardized anomalies.

Surface temperature and salinity, and bottom temperature data for the Middle Atlantic Bight and surface and bottom temperature data for the Gulf of Maine transects are presented as contoured timespace plots (Figures 10-14). Figure 15 illustrates the mean bottom depth at $5 \mathrm{~km}$ intervals of reference distance along each transect.
Annual means and departures of these variables along the transects are presented in Tables 3 and 4. Bottom temperatures in the Middle Atlantic Bight (Table 3) are averaged only over the continental shelf to a limit of approximately $197 \mathrm{~km}$ reference distance, because bottom depths further offshore exceed sampling depth of the expendable bathythermographs employed.

\section{Discussion}

\section{Middle Atlantic Bight - baseline conditions}

Baseline conditions of surface temperature across the Middle Atlantic Bight (Fig. 4A) show minimum annual values of less than $3^{\circ} \mathrm{C}$ in late February very nearshore, of $4-8^{\circ} \mathrm{C}$ during midMarch on the shelf, and of $8-20^{\circ}$ during mid-March progressing seaward of the shelf-break through the Slope and Gulf Stream water masses. The highest rate of vernal warming took place along the entire transect during late June, with peak annual temperatures of greater than $22^{\circ} \mathrm{C}$ over the shelf and greater than $26^{\circ} \mathrm{C}$ offshore achieved by late August. From August to the end of the year, temperatures declined fairly uniformly over the entire shelf, and a bit more slowly offshore. The periods of highest variability in these baseline conditions (Fig. 4B) occurred on the shelf in early June when standard deviations about the 1978-92 means were in excess of $2^{\circ} \mathrm{C}$. These variations are largely due to interannual differences in the timing of vernal warming of the surface waters of the Middle Atlantic Bight. Standard deviations in excess of $1{ }^{\circ} \mathrm{C}$ occurred over the inner shelf during the November and December period. The November variations can be partly attributed to the interannual differences of timing of the autumn overturn. The December variations were partly due to the inclusion in the base period of record-breaking, cold winter temperature values in 1978. Offshore, the standard deviations about the baseline values generally range from $2^{\circ} \mathrm{C}$ to greater than $3^{\circ} \mathrm{C}$, with the highest values along the boundary between the Slope and Gulf Stream water masses. The baseline values for this region are the most variable along the transect due to the extensive migrations of both the Shelf/Slope Front and the Gulf Stream North Wall.

The dominant features of the time-space surface salinity field across the shelf portion of the Middle Atlantic Bight transect (Fig. 5A) were the meltwater runoff from mid-March to late April, and 
TABLE 3. Water temperatures $\left({ }^{\circ} \mathrm{C}\right)$ and surface salinities (PSU) for the Middle Atlantic Bight transect.

\begin{tabular}{|c|c|c|c|}
\hline & 1996 Mean & 1978-92 Mean & 1996 Anomaly \\
\hline $\begin{array}{l}\text { Surface temperature } \\
\text { (entire transect) }\end{array}$ & 15.2 & 17.1 & -1.9 \\
\hline $\begin{array}{l}\text { Surface temperature } \\
\text { (Cont. Shelf portion) }\end{array}$ & 12.0 & 13.4 & -1.4 \\
\hline Bottom temperature ${ }^{1}$ & 8.5 & 9.3 & -0.8 \\
\hline $\begin{array}{l}\text { Surface salinity } \\
\text { (entire transect) }\end{array}$ & 32.86 & 34.03 & -1.17 \\
\hline $\begin{array}{l}\text { Surface salinity } \\
\text { (Cont. Shelf portion) }\end{array}$ & 30.74 & 32.20 & -1.46 \\
\hline
\end{tabular}

${ }^{1}$ footnote needed.

TABLE 4. Water temperatures $\left({ }^{\circ} \mathrm{C}\right)$ and surface salinities (PSU) for the Gulf of Maine transect.

\begin{tabular}{lccc}
\hline \hline & 1996 Mean & 1978-92 Mean & 1996 Anomaly \\
\hline $\begin{array}{l}\text { Surface temperature } \\
\text { (entire transect) }\end{array}$ & 8.0 & 9.1 & -1.1 \\
$\begin{array}{l}\text { Bottom temperature } \\
\text { (entire transect) }\end{array}$ & 6.9 & 6.7 & 0.2 \\
\hline
\end{tabular}

the shorter duration river discharge in mid-August, both concentrated within $30 \mathrm{~km}$ of Ambrose Tower. The Shelf-Slope Front, defined by 34.5 PSU, showed considerable spatial variation through the year, being just seaward of the shelf break from January through April, then migrating over $100 \mathrm{~km}$ further offshore by mid-June, and returning to the area seaward of the shelf break by October. Beyond the $300 \mathrm{~km}$ reference distance, salinities exceeded 36 PSU in association with meanders of the Gulf Stream. Variations about these baseline conditions (Fig. 10B) were highest nearshore where standard deviations from February through mid-June exceed 3 PSU, corresponding to the inter-annual differences in timing and magnitude of meltwater runoff. Values in excess of 1 PSU occurred throughout the year. Variations in excess of 1 PSU also occurred across the shelf in June and offshore in August and September. The influence of upstream conditions on these values (particularly outflow from the Gulf of Maine) was not easily determined from this one transect, but is thought to be a contributing factor.
Baseline conditions of bottom temperatures across the Middle Atlantic Bight shelf (Fig. 6A) showed minimum annual values of less than $2^{\circ} \mathrm{C}$ nearshore in mid-February to less than $7^{\circ} \mathrm{C}$ extending to $156 \mathrm{~km}$ reference distance in mid-March. The cold pool was a major feature of the bottom temperature regime along this transect. It occurred during the period between the onset of stratification (approximately late-March inshore, to late-April offshore) and autumn overturn (early-September nearshore to early-December offshore) (Cook, 1985; Benway et al., 1993). Autumn overturn produced maximum bottom temperatures across the shelf reaching in excess of $16^{\circ} \mathrm{C}$ nearshore and $13^{\circ} \mathrm{C}$ over most of the shelf. Variations about baseline values (Fig. 6B) showed standard deviations in excess of $3^{\circ} \mathrm{C}$ nearshore in August associated with wind mixing of these shallow waters, and upwelling and downwelling events common to that area. A large portion of the inner shelf during September and October, and the outer shelf during October and November had standard deviations of greater than 
$2{ }^{\circ} \mathrm{C}$ coinciding with inter-annual variations in the timing of autumn overturn. Beyond the $200 \mathrm{~km}$ reference distance the standard deviations exceeded $2{ }^{\circ} \mathrm{C}$ during most of the year reflecting the influence of the migrating Shelf/Slope Front on the bottom. Midshelf deviations of greater than $1{ }^{\circ} \mathrm{C}$ occurred during all but the winter months, and can be largely attributed to interannual variability in cold pool temperature, and boundaries.

\section{Gulf of Maine - Base line conditions}

Surface temperature across the Gulf of Maine transect (Fig. 7A) ranged from a minimum of less than $3^{\circ} \mathrm{C}$ over the Scotian Shelf from February to mid-April, and less than $4^{\circ} \mathrm{C}$ over Massachusetts Bay in mid-February, to a maximum of $19^{\circ} \mathrm{C}$ for Massachusetts Bay and Wilkinson Basin, and decreasing eastward to an annual maximum of $11^{\circ} \mathrm{C}$ over the Scotian Shelf in August. The highest rate of change due to vernal warming occurred during late-May through early-July across the entire transect. After August surface temperatures, with the exception of the mixed portions of the Scotian Shelf, declined rapidly. Periods of highest variability ( $>1$ standard deviation) occurred during June to late September over much of the transect and over the Western half of the transect during much of the year (Fig. 7B). Autumn overturn generally occurred during late October through early December leading to Gulf wide variability during that period. The high variations over the eastern end of the transect can be attributed to variation in the Scotian Shelf Current.

Gulf of Maine surface salinities varied less than those in the Middle Atlantic Bight, but still showed a wide range of values over the region (Fig. 8A). Salinities ranged from a minimum 30 PSU during the peak runoff into Massachusetts Bay in June, to a maximum greater than 33 PSU from Wilkinson Basin to the western Scotian Shelf between November and May. Unlike the nearshore waters of the New York Bight during late summer-early autumn, there was no secondary pulse of river runoff. The standard deviation about the baseline conditions was less than 0.5 PSU for much of the time-space area (Fig. 8B). However, deviations reaching 1 PSU occurred in April over Massachusetts Bay; between 0.5 and 0.7 PSU occurred over Crowell Basin and extended to the eastern end of the transect during January to April. In addition, standard deviations from 0.5-0.7 PSU occurred from August through December beginning over the Scotian Shelf and progressing westward to include Crowell Basin.
Bottom temperature conditions within the Gulf of Maine ranged from a minimum of less than $3^{\circ} \mathrm{C}$ over the Scotian Shelf from February through lateApril, and less than $4^{\circ} \mathrm{C}$ over Massachusetts Bay during the same time period (Fig. 9A). Mid-Gulf bottom temperatures had average minima of between 6 and $7^{\circ} \mathrm{C}$. Maximum temperatures of greater than $10^{\circ} \mathrm{C}$ occurred over the eastern end of the transect from late September through early November reaching greater than $11^{\circ} \mathrm{C}$. Maximum temperatures on the western end of the transect occurred during the same time period but only reach slightly over $8^{\circ} \mathrm{C}$. These times of maximum bottom temperature coincided with autumn overturn for these shelf areas. These maxima were absent in the basin areas which are commonly isolated from the overturn event by the Maine Intermediate Water. The largest time-space standard variations about the baseline conditions were more common over the shallower portions of the transect, i.e., Massachusetts Bay, the central Gulf ledges, and the Scotian Shelf (Fig. 9B), and amounted to greater than $1^{\circ} \mathrm{C}$. These deviations were most evident over the Scotian Shelf during late autumn and winter.

\section{Middle Atlantic Bight - 1996 conditions}

Surface and bottom temperature, and surface salinity conditions along the Middle Atlantic Bight transect during 1996 were record breaking when compared to the 1978-92 baseline. This was true for the absolute values measured and/or for the time-space extent over which they occurred.

Surface Temperature. Surface temperatures during 1996 (Fig. 10A) ranged from less than $2^{\circ} \mathrm{C}$ in the near-shore waters in February to greater than $26^{\circ} \mathrm{C}$ at the extreme off-shore end of the transect during late-August and into October. Annual minimum temperatures occurred over the entire transect in February, somewhat earlier than the 15-year base period. Particularly inshore, 1996 began with $2{ }^{\circ} \mathrm{C}$ colder than average temperatures (Fig. 10B), a carryover from 1995s colder than average December. Much of the shelf area during the period of January through late-April exhibited surface temperatures in excess of $2^{\circ} \mathrm{C}$, and isolated cases exceeded $3^{\circ} \mathrm{C}$ below average. Cold surface water was observed from February through the rest of the year in the shelf/slope region. Record breaking snowfall, increased cloud cover and reduced solar radiation (National Climatic Data Center, 1996), all contributed to the anomalous condition observed. Surface temperatures averaged for the year were $1.9^{\circ} \mathrm{C}$ 
cooler for the transect as a whole, and $1.4^{\circ} \mathrm{C}$ cooler for the shelf portion than the 1978-92 means (Table 3 ). This represents one of the largest negative departures in the Middle Atlantic Bight transect recorded by this project to date.

Surface Salinity. Surface salinities along the MAB transect during 1996 (Fig. 11) were by far lower than those of any year since monitoring began in 1978. Surface water over the inshore $35 \mathrm{~km}$ of the transect was more than 2 PSU below the 1978-92 baseline during January, and more than 3.5 PSU lower during March through early November (Fig. 11B). In May salinities off Ambrose Light declined to <17.5 PSU, over 12 PSU below average. The entire shelf was 0.5 PSU below average with a major portion of its area more than 1.4 PSU below average. Low salinity water spread to the offshore end of the transect, reaching a minimum of <33 PSU in late October. Some comparisons of 1996 to 1984 (the second most fresh condition year in the series) are noteworthy. Lowest salinities in both years occurred in May off Ambrose Light; in 1984 they declined to 22.5 PSU - in 1996 to < 17.5 PSU. In both years low salinity water spread towards the offshore end of the transect in the latter half of the year; in 1984 it declined to just under 34 PSU on two brief occasions (generally 35-36 PSU) - in 199634 PSU water was present over the outer end of the transect most of the time after June, and in October declined to <32.5 PSU.

Bottom temperature. The relationship between bathymetry and reference distance is shown in Fig. 15A. Bottom temperatures ranged from less than $4^{\circ} \mathrm{C}$ from late January to mid-March on the inner shelf to greater than $15^{\circ} \mathrm{C}$ over the inner shelf during September (Fig. 12A). Based on water column data, the annual autumn overturn began during mid-September and was nearly completed on the shelf by mid-November. The "Cold Pool", described by Cook (1985) as bottom water less than $10^{\circ} \mathrm{C}$, which normally is confined to the inner 160 $\mathrm{km}$ of the transect, was present over the entire sampled area between March and September, producing significantly negative anomalies in July (Fig. 12B). Significantly negative departures occurred over the mid-shelf from February through March and over much of the shelf in April. These coincided with an increase in coastal storms, mixing winds, and colder than normal air temperatures beginning in December 1995 (National Climatic Data Center, MS 1996). Annual means of bottom temperature on the continental shelf averaged $-0.8^{\circ} \mathrm{C}$ below the $1978-92$ baseline (Table 3 ).

\section{Gulf of Maine - 1996 conditions}

Surface temperature. Surface temperatures ranged from less than $2^{\circ} \mathrm{C}$ in Massachusetts Bay during mid-February to greater than $17^{\circ} \mathrm{C}$ in the western region of the transect during the July period (Fig. 13A). Significant negative anomalies occurred from Massachusetts Bay out to Crowell Basin during January through February, dropping over $2^{\circ} \mathrm{C}$ below the $1978-92$ means (Fig. 13B and 13C). Highly significant positive anomalies were observed during the same period on the Scotian Shelf end of the transect. These positive anomalies exceeded the baseline by over $3^{\circ} \mathrm{C}$. During July and continuing through September significant negative anomalies in the middle and eastern end of the transect were observed. These follow the lower than normal air temperature weather pattern for the New England area mentioned above (National Climatic Data Center, MS 1996). For the transect as a whole, surface temperatures averaged $8.0^{\circ} \mathrm{C}$, or $-1.1^{\circ} \mathrm{C}$ colder than 1978-92 means (Table 4).

Bottom Temperatures. The relationship between bathymetry and reference distance is shown in Fig. 15B. Annual minimum bottom temperatures for the transect of less than $3^{\circ} \mathrm{C}$ occurred in Massachusetts Bay during the February-March period (Fig. 14A). Equally low temperatures also were observed in January at the Scotian Shelf or eastern end of the transect. Maximum bottom temperatures occurred in the Crowell Basin region during January and again for a more extended period in May. Positive anomalies, reaching in excess of $3^{\circ} \mathrm{C}$, occurred over the Scotian Shelf beginning in lateApril and continued through late May (Fig. 14B). This warmer-than-normal condition continued and expanded westward to include the central Gulf ledges during the June through October period. For the transect as a whole, bottom temperatures in the Gulf of Maine exceeded the base line temperatures of $6.7^{\circ} \mathrm{C}$ by only $0.2^{\circ} \mathrm{C}$.

\section{Conclusions}

Middle Atlantic Bight surface temperatures and salinities and bottom temperatures during 1996 were lower than any period since 1978 , averaging $1.9^{\circ} \mathrm{C}, 1.17 \mathrm{PSU}$, and $0.8^{\circ} \mathrm{C}$ below the $1978-92$ baselines, respectively. The negative departure of the surface features are part of a fairly persistent 
pattern beginning in December 1995 and continuing through May 1998 (Jossi, 1998), our current data collection period.

Gulf of Maine surface temperatues averaged $1.1^{\circ} \mathrm{C}$ below the $1978-92$ baseline during 1996 , while bottom temperature averaged $0.2^{\circ} \mathrm{C}$ warmer. Unlike the Middle Atlantic Bight these 1996 conditions do not appear to be part of a longer scale pattern.

\section{Acknowledgments}

Appreciation is extended to the officers and crews of the C/V Oleander, Bermuda Container Lines, Hamilton, Bermuda; and the C/V Godafoss, Skogaline Ltd, St. John, Antigua for their generous cooperation in the continued success of this program. Appreciation also is proffered to all the volunteers who have collected data aboard the Oleander. Special thanks are extended to the members of the National Ocean Service, Office of Ocean Observations, and the National Weather Service, Eastern Region for their continued support.

\section{References}

BENWAY, R. L., J. W. JOSSI, K. P. THOMAS, and J. R. GOULET. 1993. Variability of temperature and salinity in the Middle Atlantic Bight and Gulf of Maine. MARMAP Atlas Monograph No. 4. NOAA Tech. Rep. NMFS, 112: 108 p.

BOLIN, B., D. R. DOOS, J. JAGER, and R. A. WARRICK (eds.). 1986. The greenhouse effect, climatic change, and ecosystems. Scientific Committee on Problems of the Environment (SCOPE), 29. John Wiley, N.Y.

BOWMAN, M. J., and L. D. WUNDERLICH. 1977. Hydrographic Properties. New York Sea Grant Institute, MESA New York Bight Atlas Monograph, 1, $78 \mathrm{p}$.

COLTON, J. B., JR., and R. R. STODDARD. 1973. Bottom-water temperatures on the continental shelf, Nova Scotia to New Jersey. NOAA Tech. Rep. NMFS Circ., 376: 55 p.

COOK, S. K. 1985. Temperature Conditions in the Cold Pool 1977-1981: a Comparison Between Southern New England and New Your Transects. NOAA Tech Rep. NMFS, 24: $22 \mathrm{p}$.

FRANK, K. T., R. I. PERRY, K. F. DRINKWATER, and W. H. LEAR. 1988. Changes in the fisheries of Atlantic Canada associated with global increases in atmospheric carbon dioxide: a preliminary report. Can. Tech. Rep. Fish. Aquat. Sci., 1652: 52 p.

GEORGI, D. T., J. P. DEAN, and J. A. CHASE. 1980. Temperature calibration of expendable bathythermo- graphs. Ocean Resour. Eng., 7: 491-499.

GLOBEC. 1989. Report of a workshop on global ocean ecosystems dynamics. Wintergreen, VA, May 1988. Joint Oceanographic Institutions Inc. Washington, D.C. (Available from Joint Oceanographic Institutions, Inc. Washington, D.C.)

1991. Report Number 1. Initial science plan. February 1991. (Available from Joint Oceanographic Institutions Inc. Washington, D.C.)

Report Number 2. GLOBEC: Northwest Atlantic Program, GLOBEC Canada/U.S. meeting on N.W. Atlantic fisheries and climate, February, 1991. (Available from Joint Oceanographic Institutions Inc. Washington, D.C.)

GLOVER, R. S. 1967. The continuous plankton recorder survey of the North Atlantic. Symp. Zool. Soc. Lond., 19: $189-210$.

INGHAM, M. C. (ed.). 1982. Summary of the physical oceanographic processes and features pertinent to pollution distribution in the coastal and offshore waters of the northeastern United States, Virginia to Maine. NOAA Tech. Mem. NMFS-F/NEC, 17: 166 $\mathrm{p}$.

JOSSI, J. W. 1998. Northeast Marine Ecosystem Indices. [http://narwahl.gso.uri.edu/cwatch.html. hardcopy available from: NOAA Narragansett Loaboratory, 28 Tarzwell Drive, Narragansett, RI 02882].

MEISE-MUNNS, C., J. GREEN, M. INGHAM, and D. MOUNTAIN. 1990. Interannual variability in the copepod populations of Georges Bank and the western Gulf of Maine. Mar. Biol. Prog. Ser., 65: 225232.

MOUNTAIN, D.G. and J. P. MANNING. 1994. Seasonal and interannual variability in the properties of the surface water of the Gulf of Maine. Continental Shelf Res., 14: 1555-1581.

NATIONAL CLIMATIC DATA CENTER. MS 1996. Local climatological data monthly summary. Boston, Providence, and JFK Airport, December 95 through December 96. (Available from: National Climatic Data Center, Federal Building, 37 Battery Park Ave., Ashville, NC 28801.]

SHERMAN, K. 1980. MARMAP, a fisheries ecosystem study in the northwest Atlantic: Fluctuations in ichthyoplankton-zooplankton components and their potential for impact on the system. pp. 9-37. In: F. P. Diemer, F. J. Vernberg, and D. Z. Mirkes (eds.), Advanced Concepts in Ocean Measurements for Marine Biology, 572 p. University of South Carolina Press, Columbia, S.C.

SIPPICAN CORPORATION. 1970. XBT system linearity equation. Ocean Engineering Bulletin, No. 1.

STEINHART, J. S., AND S. R. HART. 1968. Calibration curves for thermistors. Deep Sea Res.Oceanogr. Abstr., 15: 497-503.

THOMAS, K. P. MS 1992. Initiation and decline of Ceratium Tripos blooms in the Gulf of 
Maine: Dependence upon water column structure. Ms. Thesis Univ. of R.I., 127 p.

UNESCO. 1981. Background papers and supporting data on the practical salinity scale 1978 . Unesco Technical Papers in Marine Science, Vol. 37. Unesco, Paris, $144 \mathrm{p}$. 